\title{
Water-soluble organic carbon in snow and ice deposited at Alpine, Greenland, and Antarctic sites: a critical review of available data and their atmospheric relevance
}

\author{
M. Legrand ${ }^{1}$, S. Preunkert ${ }^{1}$, B. Jourdain ${ }^{1}$, J. Guilhermet ${ }^{1}$, X. Faïn ${ }^{1}$, I. Alekhina ${ }^{2}$, and J. R. Petit ${ }^{1}$ \\ ${ }^{1}$ CNRS/UJF-Grenoble 1, Laboratoire de Glaciologie et Géophysique de l'Environnement du Centre National de la Recherche \\ Scientifique (LGGE), UMR5183, Grenoble 38041, France \\ ${ }^{2}$ Arctic and Antarctic Research Institute, 38 Bering St., St. Petersburg 199397, Russia \\ Correspondence to: M. Legrand (legrand@lgge.obs.ujf-grenoble.fr)
}

Received: 20 April 2013 - Published in Clim. Past Discuss.: 7 May 2013

Revised: 16 July 2013 - Accepted: 5 August 2013 - Published: 16 September 2013

\begin{abstract}
While it is now recognized that organic matter dominates the present-day atmospheric aerosol load over continents, its sources remain poorly known. The studies of organic species or organic fractions trapped in ice cores may help to overcome this lack of knowledge. Available data on the dissolved (or total) organic carbon (DOC or TOC) content of snow and ice often appear largely inconsistent, and, until now, no critical review has been conducted to understand the causes of these inconsistencies. To draw a more consistent picture of the organic carbon amount present in solid precipitation that accumulates on cold glaciers, we here review available data and, when needed, complete the data set with analyses of selected samples. The different data sets are then discussed by considering the age (modern versus pre-industrial, Holocene versus Last glacial Maximum) and type (surface snow, firn, or ice) of investigated samples, the deployed method, and the applied contamination control. Finally, the OC (DOC or TOC) levels of Antarctic, Greenland, and Alpine ice cores are compared and discussed with respect to natural (biomass burning, vegetation emissions) and anthropogenic sources (fossil fuel combustion) contributing to atmospheric OC aerosol.
\end{abstract}

\section{Introduction}

Although the carbonaceous matter that includes elemental carbon (EC) and organic carbon (OC) is recognized as a major constituent of present-day atmospheric aerosol over con- tinents (Putaud et al., 2004; Legrand and Puxbaum, 2007; Jimenez et al., 2009), there are still major gaps with respect to its sources. In the present-day continental atmosphere, on a mass carbon basis, the EC (or black carbon, BC) fraction accounts only for $15 \%$ of carbonaceous aerosol (see Pio et al. (2007) for Europe), while the dominant fraction consists of organic carbon (OC). Whereas it is rather well established that secondary production dominates primary emissions of organic carbon (OC) aerosol, the chemical nature of gaseous precursors (natural/anthropogenic) and mechanisms involved in its production remain poorly understood (Turpin et al., 2000; Simpson et al., 2007). These deficits in knowledge lead to an overall model underestimation of atmospheric OC aerosol concentrations (for a review, see Hodzic et al., 2010). It is also important to note that in the continental atmosphere the water-soluble fraction of OC (WSOC) generally dominates the water-insoluble one (WinOC) (Pio et al., 2007).

The relative contributions of natural (e.g. vegetation emissions) compared to anthropogenic (e.g. fossil fuel combustion) sources of $\mathrm{OC}$ aerosol for the present-day atmosphere as well as the variability of natural sources over the past can to some extent be highlighted by snow and ice core studies. Indeed, the study of chemical impurities trapped in solid precipitation accumulated over the past on polar ice sheets and mid-latitude cold glaciers represents a unique and powerful way to reconstruct our changing atmosphere from the pre-industrial era to present day (see Legrand and Mayewski, 1997, for a review). In this way, ice core studies of sulfate have already permitted evaluation of the impact of 
growing anthropogenic $\mathrm{SO}_{2}$ emissions on the atmospheric aerosol load over various regions of the Northern Hemisphere (Mayewski et al. (1986) and Fischer et al. (1998) for Greenland; Schwikowski et al. (1999), Preunkert et al. (2001), and Fagerli et al. (2007) for the Alps). In contrast, information on the load and composition of the organic matter archived in ice are still very limited.

Studies dealing with organic species trapped in ice focused on water-soluble organic gases like formaldehyde (HCHO) (Staffelbach et al., 1991; Hutterli et al., 2003) in relation to the oxidative capacity of the atmosphere, and monocarboxylic acids (mainly formic $(\mathrm{HCOOH})$ and acetic $\left(\mathrm{CH}_{3} \mathrm{COOH}\right)$ acids) in relation to either boreal forest fires (Legrand et al., 1992; Savarino and Legrand, 1998), vegetation emissions (Legrand and De Angelis, 1995, 1996), or vehicular emissions (Legrand et al., 2003). Concerning organic aerosol, studies started with methanesulfonate $\left(\mathrm{CH}_{3} \mathrm{SO}_{3}^{-}\right.$(denoted $\mathrm{MS}^{-}$) or methanesulfonic acid (denoted MSA)), an organic sulfur aerosol that was investigated in numerous Greenland (Legrand et al., 1997; Saltzman et al., 1997) and Antarctic (Legrand, 1997; Wolff et al., 2006) ice cores with a view to reconstruct past marine biogenic emissions of dimethylsulfide (DMS). A few ice core studies also documented organic aerosols like $\mathrm{C}_{2}-\mathrm{C}_{5}$ dicarboxylates (Legrand et al., 2007a), long-chain $\left(\mathrm{C}_{14}-\mathrm{C}_{22}\right)$ carboxylates (Kawamura et al., 1996) and humic-like substances (HULIS) (Calace et al., 2005; Guilhermet et al., 2013). Finally, though being present at levels more than 2 orders of magnitude lower than those of other organic species, polycyclic aromatic hydrocarbons (PAHs) were also investigated in an Alpine ice core (Gabrieli et al., 2010).

In addition to these investigations of individual organic species, several studies were dedicated to the evaluation of the amount of total OC (TOC) or dissolved OC (DOC) present in snow and ice from Greenland, Antarctica, and the Alps. Though TOC (but not DOC) accounts for waterinsoluble organic matter, the observed large difference between data cannot be explained by the presence of insoluble OC. For instance, whereas biogenic organic species able to produce organic aerosol within the atmosphere are mainly emitted by vegetation present on continents, some OC concentrations reported for pre-industrial ice extracted at Antarctic sites are unexpectedly higher $(80-360 \mathrm{ppbC}$ reported as TOC, Federer et al., 2008) than those reported for Greenland (10-40 ppbC reported as DOC, Preunkert et al., 2011) and Alpine (45-98 ppbC reported as DOC, Preunkert et al., 2011) pre-industrial ice. Furthermore, available data on the pre-industrial Antarctic level range from less than $10 \mathrm{ppbC}$ (reported as DOC, Preunkert et al., 2011) to 80$360 \mathrm{ppbC}$ (reported as TOC, Federer et al., 2008).

With the aim to improve our understanding of these discrepancies, this paper carefully reviews available OC (DOC or TOC) data and, when needed, provides new ones on selected snow and ice samples. The new data include measurements of surface snow and snow pit samples collected under stringent conditions in Antarctica and in the Alps. In addition, investigations were also carried out on selected sections of pre-industrial Greenland ice extracted at the sites of Summit and NEEM (including ice layers with boreal forest fire inputs), as well as on Antarctic ice core sections covering the last great climate change (from the Last Glacial Maximum to the Holocene). Finally, several organic carbon fractions including WSOC and HULIS were investigated in Antarctica in the 2011 year-round atmospheric aerosol sampling carried out at Concordia station located close to the Dome C drilling site. These unique WSOC aerosol data from the lower atmosphere of the East Antarctic Plateau are compared to corresponding data already available from central Greenland or from a high-elevated Alpine site.

\section{Experimental section}

\subsection{Organic carbon analysis}

The device we used in this study to quantify the DOC content in snow and ice samples is based on the commercial Phoenix 8000 system (Teledyne Tekmar Company), which was modified to allow for precise analysis of small sample volumes of $\sim 5 \mathrm{~mL}$ (Preunkert et al., 2011). Given the fact that inconsistencies related to the amount of organic carbon present in snow and ice may partly be induced by differences in the employed method (see Sect. 3.2.1), we here concisely detail our working conditions. The liquid sample is first introduced into an inorganic carbon sparger cell together with phosphoric acid and sparged to drive off any inorganic carbon (dissolved $\mathrm{CO}_{2}, \mathrm{HCO}_{3}^{-}$, and $\mathrm{CO}_{3}^{2-}$ ). Next, the liquid sample is transferred from the inorganic carbon cell to a UV reactor cell, where a UV lamp together with an oxidant oxidizes the organic carbon into $\mathrm{CO}_{2}$. As discussed by Preunkert et al. (2011), to reach blank values as low as possible, no addition of oxidant solution in the UV reactor is done, and instead synthetic air is used as carrier gas from which $\mathrm{O}_{2}$ increases the oxidation efficiency. The hereby produced $\mathrm{CO}_{2}$ within the UV reactor is swept together with the carrier gas into a non-dispersive infrared (NDIR) detector.

Over the course of a day of sample analysis, 3-5 blank measurements were made showing a typical mean $( \pm 1 \sigma)$ of $25 \pm 1.5 \mathrm{ppbC}$. The respective daily mean blank value is subtracted from the sample values. Taken as twice the standard deviation of the blanks made over a day, the detection limit is about 3 to $5 \mathrm{ppbC}$. The typical uncertainty of our method, calculated by considering the uncertainty on the determination of the slope of the calibration curve and the variability of the blank value, is of $4 \%$ for samples containing more than $50 \mathrm{ppbC}$. Due to the blank variability the uncertainty reaches $35 \%$ at the 5 ppbC level.

Under working conditions applied in this study, the efficiency of the oxidation relative to the potassium hydrogen phthalate was found to range from 85 to $125 \%$ for different 
water-soluble organic molecule standards (see details in Preunkert et al., 2011). This is true for organic species present at significant levels in natural ice such as short-chain monoand dicarboxylic acids and formaldehyde, as well as for a few other compounds whose presence in ice is expected but not yet quantified (i.e., methanol, and $\mathrm{C}_{2}-\mathrm{C}_{3}$ aldehydes as glyoxal, methyl glyoxal, and glycolaldehyde). For long-chain polyacids that are also present in snow, such as HULIS, the efficiency of the oxidation was found to be slightly lower, i.e. $80 \pm 2 \%$. The extent to which this method oxidizes the water-insoluble organic material present in snow and ice, and thus measures TOC rather than DOC, will be discussed in Sect. 3.2.1.

\subsection{Ancillary chemical analysis}

Most snow and ice samples in which the organic carbon content was measured in this study were also investigated for ions. For cations $\left(\mathrm{Na}^{+}, \mathrm{K}^{+}, \mathrm{Mg}^{2+}, \mathrm{Ca}^{2+}\right.$, and $\left.\mathrm{NH}_{4}^{+}\right)$, a Dionex ICS-1000 chromatograph equipped with CG12 and CS12 separator columns was used. For anions, a Dionex DX600 equipped with AG11 and AS11 separator columns was run with a quaternary gradient of eluents $(2.5 \mathrm{mM} \mathrm{NaOH}$, $100 \mathrm{mM} \mathrm{NaOH}, 90 \% \mathrm{CH}_{3} \mathrm{OH}$ in $\mathrm{H}_{2} \mathrm{O}$, and $\mathrm{H}_{2} \mathrm{O}$ ). A gradient pump system allows for the determination of inorganic species $\left(\mathrm{F}^{-}, \mathrm{Cl}^{-}, \mathrm{NO}_{3}^{-}\right.$, and $\left.\mathrm{SO}_{4}^{2-}\right)$ as well as short-chain carboxylates. Investigated carboxylates including formate $\left(\mathrm{HCO}_{2}^{-}\right)$, lactate $\left(\mathrm{CH}_{3} \mathrm{CHOHCO}_{2}^{-}\right)$, acetate $\left(\mathrm{CH}_{3} \mathrm{CO}_{2}^{-}\right)$, glycolate $\left(\mathrm{CH}_{2} \mathrm{OHCO}_{2}^{-}\right)$, glyoxylate $\left(\mathrm{CHOCO}_{2}^{-}\right)$, oxalate $\left(\mathrm{C}_{2} \mathrm{O}_{4}^{2-}\right)$, malate $\left(\mathrm{CO}_{2} \mathrm{CH}_{2} \mathrm{CHOHCO}_{2}^{2-}\right)$, malonate $\left(\mathrm{CO}_{2} \mathrm{CH}_{2} \mathrm{CO}_{2}^{2-}\right)$, succinate $\left(\mathrm{CO}_{2}\left(\mathrm{CH}_{2}\right)_{2} \mathrm{CO}_{2}^{2-}\right)$, and glutarate $\left(\mathrm{CO}_{2}\left(\mathrm{CH}_{2}\right)_{3} \mathrm{CO}_{2}^{2-}\right)$. The detection limits for major ions like ammonium, nitrate, and sulfate are close to $1 \mathrm{ppb}$, while those for most carboxylates close to $0.1 \mathrm{ppb}$.

In addition to short-chain carboxylates, other potential contributors to the DOC content of solid precipitation like short-chain aldehydes were investigated in some samples. First, HCHO was measured in a few snow pit samples collected at Concordia and in the Alps as well as in a few ice core sections from the Greenland NEEM site. Measurements were done with a fluorimetric method that is based on the liquid-phase reaction of formaldehyde with acetyl acetone and a $\mathrm{CH}_{3} \mathrm{COONH}_{4}-\mathrm{CH}_{3} \mathrm{COOH}$ mixture (Hantzsch reagent). The deployed analyser (Aerolaser AL4021) has a detection limit of $0.1 \mathrm{ppb}$ (Legrand et al., 2007a). A few measurements of some other carbonyl compounds including acetaldehyde, propionaldehyde, and acetone were achieved in Alpine surface snow as well as in Alpine ice covering the 1940s period (Houdier et al., 2000). Here, only acetaldehyde was detected at a significant level ( $\sim 4$ ppb, i.e. 2 ppbC).

Water-soluble HULIS were investigated in several snow pit samples collected at Concordia and in the Alps. HULIS were extracted with a DEAE (diethylaminoethyl) resin, and the quantification of their organic carbon content was made with a Shimadzu TOC analyser (Guilhermet et al., 2013).

\subsection{Sampling and subsampling of snow and ice}

The DOC (or TOC; see discussions in Sect. 3.2.1) content was investigated in various snow and ice samples collected on polar ice sheets (Antarctica and Greenland) as well as at the high-elevated Alpine site of the Col du Dôme (4250 m a.s.l., Mont Blanc Massif, French Alps). It has to be emphasized that the measurement of DOC, which is present at trace levels in precipitation of remote regions, is very sensitive to contamination from numerous organic gases present in the ambient air of laboratories. Thus the DOC (or TOC) content of snow deposits has been documented until now only in snow samples collected under stringent conditions near the surface or in snow pits but not in firn cores.

\subsubsection{Surface snow and snow pits}

With only two studies conducted in Antarctica (at the South Pole and coastal areas, Table 1) and two studies performed at Summit in central Greenland (Table 2), the OC content of the surface snow pack remains poorly documented (see Sect. 3 ). Unexpectedly, with several hundreds of ppbC of TOC, the Antarctic snow (both coastal and inland) appears as rich in $\mathrm{OC}$ as the central Greenland one. Furthermore, the two central Greenland studies show differences by a factor of 4 in the OC abundance of surface snow (Table 2). With the aim to enlarge this rather inconsistent data set, surface snow and snow pit samples were collected at Concordia, located on the high East Antarctic Plateau, and at the Col du Dôme in the Mt Blanc massif. At Concordia, surface snow (0 to 5 and 5 to $10 \mathrm{~cm}$ depth) was collected in January 2010. Furthermore, 24 snow samples were collected in a $1 \mathrm{~m}$ deep snow pit dug in January 2012 at Concordia (Table 1).

At the Col du Dôme, the surface snow layer corresponding to a 3-day old snow precipitation event (having occurred 14 September 2012) was sampled (4 samples between 0 and $20 \mathrm{~cm}$ depth), together with the uppermost $1.5 \mathrm{~m}$ of the snowpack permitting documentation of the snow deposited during the entire summer 2012 as well as the winter 2011/2012 (18 samples). These snow pit samples were collected to document the very recent levels that cannot be examined within firn cores (see Sect. 2.3), limiting examination of temporal trends to the end of the 1980 s (i.e., at the age of the firn/ice transition at the site). Finally, four surface summer snow samples were collected in June 2011 (Table 2).

All samples were collected in airtight glass bottles (Schott, Mainz, Germany) of different sizes (from $100 \mathrm{~mL}$ to $5 \mathrm{~L}$ ). Indeed, whereas $100 \mathrm{~mL}$ bottles are adequate for DOC sampling, even for samples containing less than $5 \mathrm{ppbC}$ of DOC, a volume of $500 \mathrm{~mL}$ of melted snow is needed to reach a HULIS detection limit of $1 \mathrm{ppbC}$ as required for Antarctic snow and for Alpine winter snow layers. Glass bottles 
Table 1. Organic carbon content measured in snow and ice from various Antarctic sites. TOC refers to total organic carbon concentrations obtained with a catalytic combustion (CC) method. All other values that were obtained with a UV oxidation method without filtration of samples would correspond to dissolved organic carbon (DOC). However, as discussed in Sect. 3.2.1, a large part of the particulate organic fraction present at levels of a few ppbC (i.e., less than $10 \%$ of DOC) in Antarctic snow and ice would have been oxidized even when using a UV method. For the methods, $\mathrm{NDIR} \mathrm{CO}_{2}$ refers to a non-dispersive infrared $\mathrm{CO}_{2}$ detector, and Conduc. to a $\mathrm{CO}_{2}$ electrolytic conductivity detector. PE denotes the use of polyethylene vials. $\mathrm{S}$ refers to summer season. $\mathrm{N}$ is the number of analysed samples.

\begin{tabular}{|c|c|c|c|c|c|}
\hline Sites, Elevation (m a.s.l.) & Material, Age & $\mathrm{OC}$ in $\mathrm{ppbC}(\mathrm{N})$ & Method & Vials & References \\
\hline South Pole (2850) & Surface snow, S $2001 \mathrm{AD}$ & $\mathrm{TOC}=400 \pm 130$ & $\mathrm{CC} / \mathrm{NDIR} \mathrm{CO}_{2}$ & $\mathrm{PE}$ & Grannas et al. (2004) \\
\hline Concordia (3250) & Surface snow, S 2010 AD & $14-27(2)$ & $\mathrm{UV} / \mathrm{NDIR} \mathrm{CO}_{2}$ & Glass & This work \\
\hline Concordia (3250) & Snow pit, 2002-2012 AD & $10-150^{* *}(24)$ & $\mathrm{UV} / \mathrm{NDIR} \mathrm{CO}_{2}$ & Glass & This work \\
\hline Princess Elizabeth Land (0-2210) & Surface snow* & $88<\mathrm{TOC}<928$ & $\mathrm{CC} / \mathrm{NDIR} \mathrm{CO}_{2}$ & $\mathrm{PE}$ & Antony et al. (2011) \\
\hline Dronning Maud Land (610-3015) & Surface snow* & $13<\mathrm{TOC}<345(20)$ & $\mathrm{CC} / \mathrm{NDIR} \mathrm{CO}_{2}$ & $\mathrm{PE}$ & Antony et al. (2011) \\
\hline Victoria Land, Antarctic coast & Snow pit, 1989-2000 AD & TOC $<96$ & $\mathrm{CC} / \mathrm{NDIR} \mathrm{CO}_{2}$ & $\mathrm{PE}$ & Lyons et al. (2007) \\
\hline Vostok (3488) & Ice, $9970 \mathrm{BP}$ & $5.2 \pm 1.7(7)$ & $\mathrm{UV} / \mathrm{NDIR} \mathrm{CO}_{2}$ & Glass & Preunkert et al. (2011) \\
\hline Vostok (3488) & Ice, $8300 \mathrm{BP}$ & $5.8 \pm 1.4(3)$ & $\mathrm{UV} / \mathrm{NDIR} \mathrm{CO}_{2}$ & Glass & This work \\
\hline D47 (1500) & Ice, $1280 \mathrm{AD}$ & $1.7 \pm 1.7(2)$ & $\mathrm{UV} / \mathrm{NDIR} \mathrm{CO}_{2}$ & Glass & Preunkert et al. (2011) \\
\hline D47 (1500) & Ice, $1660 \mathrm{AD}$ & $6.2 \pm 5.8(7)$ & $\mathrm{UV} / \mathrm{NDIR} \mathrm{CO}_{2}$ & Glass & This work \\
\hline South Pole (2850) & Ice, $1010 \mathrm{BP}$ & $7.4(1)$ & $\mathrm{UV} / \mathrm{NDIR} \mathrm{CO}_{2}$ & Glass & Preunkert et al. (2011) \\
\hline Dome C (3240) & Ice, $10300 \mathrm{BP}$ & $21.1 \pm 4.5$ & $\mathrm{UV} / \mathrm{NDIR} \mathrm{CO}_{2}$ & Glass & This work \\
\hline Dome C (3240) & Ice, $19600 \mathrm{BP}$ & $14.5 \pm 5.4(7)$ & $\mathrm{UV} / \mathrm{NDIR} \mathrm{CO}_{2}$ & Glass & This work \\
\hline Caroline $(\sim 1320)$ & Ice, Holocene & $10.9 \pm 3.7(9)$ & $\mathrm{UV} / \mathrm{NDIR} \mathrm{CO}_{2}$ & Glass & This work \\
\hline Caroline $(\sim 1550)$ & Ice, Holocene & $9.0 \pm 4.5(8)$ & $\mathrm{UV} / \mathrm{NDIR} \mathrm{CO}_{2}$ & Glass & This work \\
\hline Caroline $(\sim 3000)$ & Ice, LGM & $5.0 \pm 3.8(7)$ & $\mathrm{UV} / \mathrm{NDIR} \mathrm{CO}_{2}$ & Glass & This work \\
\hline Caroline $(\sim 3000)$ & Ice, LGM & $5.3 \pm 3.7(16)$ & $\mathrm{UV} / \mathrm{NDIR} \mathrm{CO}_{2}$ & Glass & This work \\
\hline Talos Dome (2300) & Ice, $4350-4650 \mathrm{BP}$ & $80-360$ (continuous) & UV/Conduc. & - & Federer et al. (2008) \\
\hline
\end{tabular}

* Sampling year not specified. ${ }^{* *}$ Numerous samples were contaminated following difficulties in properly closing the cap of glass bottle at cold temperatures (see details in Sect. 2.3.1).

Table 2. Same as Table 1 but for OC content of snow and ice from various Greenland sites and the Alps. Values are reported as DOC when samples that were measured with a UV oxidation method were previously filtered to remove particulate organic material (see Sect. 3.2.1). All other values that were obtained with a UV oxidation method without filtration of samples would correspond to TOC and DOC in the case of snow and ice from Greenland and the Alps, respectively (see Sect. 3.2.1).

\begin{tabular}{|c|c|c|c|c|c|}
\hline Sites, Location, Elevation (m a.s.l.) & Material, Age (AD) & $\mathrm{OC}$ in $\mathrm{ppbC}(\mathrm{N})$ & Method & Vials & References \\
\hline Summit, central Greenland (3240) & Surface snow, S 2006 & $\mathrm{DOC}=111 \pm 45(\mathrm{~S})(219)$ & UV/Conduc. & Glass & Hagler et al. (2007a) \\
\hline Summit, central Greenland (3240) & Snow pit, 2001-2002 & $400(\mathrm{~W})<$ TOC $<580(\mathrm{~S})(4)$ & $\mathrm{CC} / \mathrm{NDIR} \mathrm{CO}_{2}$ & $\mathrm{PE}$ & Grannas et al. (2004) \\
\hline Summit, central Greenland (3240) & Snow pit, 2002-2006 & $20(\mathrm{~W})<\mathrm{DOC}<55(\mathrm{~S})(29)$ & UV/Conduc. & Glass & Hagler et al. (2007a) \\
\hline Summit, central Greenland (3240) & Ice, 1020 & $10(\mathrm{~W})-40(\mathrm{~S})(10)$ & UV/NDIR $\mathrm{CO}_{2}$ & Glass & Preunkert et al. (2011) \\
\hline Summit, central Greenland (3240) & Ice, $1557-1559$ & $8(\mathrm{~W})-35(\mathrm{~S})(22)$ & $\mathrm{UV} / \mathrm{NDIR} \mathrm{CO}_{2}$ & Glass & This work \\
\hline Summit, central Greenland (3240) & Ice, $1400-1402$ & $6(\mathrm{~W})-20(\mathrm{~S})(20)$ & $\mathrm{UV} / \mathrm{NDIR} \mathrm{CO}_{2}$ & Glass & This work \\
\hline Summit, central Greenland (3240) & Ice, $1298-1300$ & $6(\mathrm{~W})-80^{\mathrm{bb}}(\mathrm{S})(21)$ & $\mathrm{UV} / \mathrm{NDIR} \mathrm{CO}_{2}$ & Glass & This work \\
\hline NEEM site, Greenland (2450) & Ice, 684-686 & $10(\mathrm{~W})-33(\mathrm{~S})(6)$ & $\mathrm{UV} / \mathrm{NDIR} \mathrm{CO}_{2}$ & Glass & This work \\
\hline NEEM site, Greenland (2450) & Ice, $1465-1466$ & $17-116^{\mathrm{bb}}(8)$ & $\mathrm{UV} / \mathrm{NDIR} \mathrm{CO}_{2}$ & Glass & This work \\
\hline Dye 3, Greenland (2486) & Snow pit, 1982-1984 & $30(\mathrm{~W})-320(\mathrm{~S})(19)$ & $\mathrm{UV} / \mathrm{NDIR} \mathrm{CO}_{2}$ & Glass & Twickler et al. (1986) \\
\hline Mt. Blanc, French Alps (4250) & Surface snow, Sep. 2012 & $107 \pm 12(4)$ & $\mathrm{UV} / \mathrm{NDIR} \mathrm{CO}_{2}$ & Glass & This work \\
\hline Mt. Blanc, French Alps (4250) & Snow pit, 2011 & $304(S)(4)$ & $\mathrm{UV} / \mathrm{NDIR} \mathrm{CO}_{2}$ & Glass & This work \\
\hline Mt. Blanc, French Alps (4250) & Snow pit, 2012 & $70(\mathrm{~W})-210(\mathrm{~S})(18)$ & $\mathrm{UV} / \mathrm{NDIR} \mathrm{CO}_{2}$ & Glass & This work \\
\hline Mt. Blanc, French Alps (4250) & Ice, 1952-1976 & $270^{*}(\mathrm{~S})(26)$ & $\mathrm{UV} / \mathrm{NDIR} \mathrm{CO}_{2}$ & Glass & Legrand et al. (2007a) \\
\hline Mt. Blanc, French Alps (4250) & Ice, 1971-1988 & $86(\mathrm{~W})-201(\mathrm{~S})(137)$ & $\mathrm{UV} / \mathrm{NDIR} \mathrm{CO}_{2}$ & Glass & Legrand et al. (2013) \\
\hline Mt. Blanc, French Alps (4250) & Ice, 1925-1936 & $45(\mathrm{~W})-98(\mathrm{~S})(105)$ & $\mathrm{UV} / \mathrm{NDIR} \mathrm{CO}_{2}$ & Glass & Preunkert et al. (2011) \\
\hline Mt. Blanc, French Alps (4250) & Ice, $1925-1936$ & $128^{*}(\mathrm{~S})(4)$ & $\mathrm{UV} / \mathrm{NDIR} \mathrm{CO}_{2}$ & Glass & Legrand et al. (2007a) \\
\hline Mt. Blanc, French Alps (4250) & Ice, 1921-1951 & $44(\mathrm{~W})-91(\mathrm{~S})(335)$ & $\mathrm{UV} / \mathrm{NDIR} \mathrm{CO}_{2}$ & Glass & Legrand et al. (2013) \\
\hline
\end{tabular}

* Blank corrected value from Legrand et al. (2007a). When seasonally resolved, data are reported for summer (S) and winter (W). bb refer to values observed in layers from Summit and NEEM containing input from biomass burning events (see Figs. 1 and 2).

were cleaned by rinsing them several times with ultrapure water (Purelab Ultra MK2 analytic system commercialized by ELGA LabWater/VWS (UK) Ltd, organic content of less than 2 ppbC) a few hours to days before sampling, and then tightly closed until sampling. At Concordia, snow samplings were conducted in the clean-air sector located at a few 

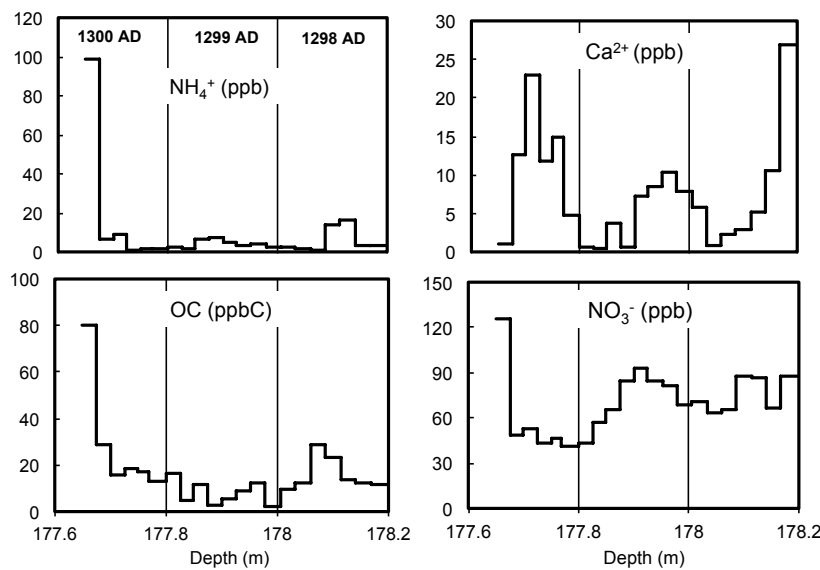

Fig. 1. Concentrations of ammonium, calcium, nitrate, and organic carbon along a $55 \mathrm{~cm}$ long ice core section extracted at Summit (central Greenland). Vertical lines refer to winter characterized by nitrate and ammonium minima, and sodium maximum (not shown). The calcium maximum is in spring. Note that, except in 1299 AD, the $\mathrm{OC}$ concentrations are higher in summer than in winter. As discussed in Sect. 3.1, the presence of a high level of OC (DOC or TOC within $10 \%$ uncertainty; see Sect. 3.2.1) in summer 1300 AD corresponds to a forest fire event as indicated by the large amount of ammonium and formate present in this layer (see also Fig. 2).

hundred metres upwind from the main station. When needed, the snow sampling was done with a glass scraper that had previously been washed with ultrapure ELGA water.

Blank measurements of the glass bottle cleaning and storage procedure were made by analysing the DOC content of an ultrapure water volume of about $20 \%$ the volume of the bottle (i.e. similar to the minimum sample liquid volume collected by filling the bottle completely with snow) poured into the respective bottles. The blank value was found to be close to the detection limit of 3-5 ppbC when blank measurements were performed no later than a few hours after the cleaning. Tests made on blank bottles, which were put in sealed plastic bags together with those used to collect snow, revealed, however, that contamination took place during the storage time between cleaning, sampling, and analysis. A typical bottle blank value of 30-50 ppbC was observed when glass bottles were stored for two days in the lab after cleaning. Such a contamination over time of airtight glass bottles is consistent with observations from Preunkert et al. (2011), who reported a mean contamination of 0.13 and $25 \mathrm{ppbCh}^{-1}$ in a $4 \mathrm{~mL}$ volume of ultrapure water put in a $100 \mathrm{~mL}$ airtight glass bottle stored in the clean room and in a "general purpose" room of the lab, respectively. Note that when glass bottles were cleaned well before their use to sample snow, larger blank values were observed. For instance, the glass bottle blank of the flasks designed to sample a snow pit at Vostok (not shown) revealed a value close to $160 \mathrm{ppbC}$, likely due to the storage over several months under various atmospheres before and after the snow sampling. Therefore, the cleaning of

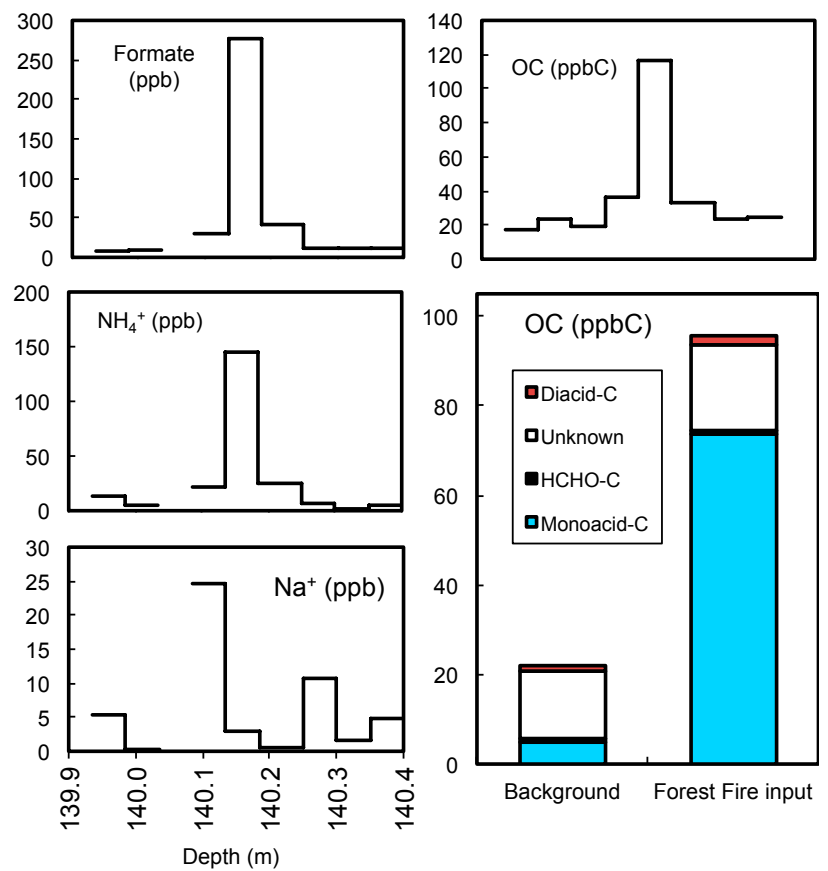

Fig. 2. Chemical signature of a forest fire event recorded in the NEEM ice site (dated to $1465 \mathrm{AD}$; see Sect. 2.3.2). Characterized by a large amount of ammonium and formate, the event took place in summer, as suggested by the sodium minimum of this layer. Comparison of the organic carbon speciation along and outside the event (bottom right) indicates an input of OC (DOC or TOC within $10 \%$ uncertainty; see Sect. 3.2.1) mainly in the form of formate, and to a lesser extent dicarboxylates and other unidentified organic species (see Sect. 6.2).

bottles before snow samples were collected within this study (see Tables 1 and 2) was done only a few hours to three days before sampling, and a storage bottle blank was systematically analysed. With these precautions bottle blank values generally remained below $25 \mathrm{ppbC}$. Since these values are significant with respect to measured snow concentrations, the corresponding glass bottle blank of the sampling series was subtracted from snow concentrations.

Another problem related to the use of Schott glass bottles for sampling snow appears at the very low temperatures encountered in Antarctica $\left(-30^{\circ} \mathrm{C}\right)$. At these temperatures, snow grains that stick to the glass thread do not melt even when compressed in the thread plug of the glass bottle during closure of bottle. Thus the bottle cap does not close properly, and significant contamination takes place during melting of the sample at ambient lab temperature. For instance, on a total of 24 bottles used to collect snow pit samples at Concordia in 2012, nine bottles were found to remain well closed during the melting step, whereas 15 bottles were not closed tightly, showing higher DOC content $(82 \pm 24 \mathrm{ppbC}$ instead of $30 \pm 20 \mathrm{ppbC}$ ). 


\subsubsection{Ice core subsampling}

DOC investigations were conducted in ice cores extracted at various locations in Antarctica and Greenland, as well as at the Col du Dôme Alpine site. With the aim to investigate change of the DOC level with respect to the proximity of the ocean in Antarctica, investigations were made on ice cores extracted at the high plateau (Vostok and Dome C) as well as at sites located closer to the coast (i.e. in the D47 core and at the top of the Caroline ice core drilled at the coast) (Table 1). The ages of the ice samples from the Antarctic ice cores were estimated by Parennin et al. (2004) for Vostok, by Jouzel et al. (1989) for Dome C, and by Ciais et al. (1994) for D47. In the case of the Caroline ice core drilled in the margin area of East Antarctica (Yao et al., 1990), the ice from increasing core depth originates from increasing distance from the coast. In Table 1, based on the study from Lorius and Merlivat (1997), we report therefore an estimate of the altitude origin of the investigated ice core sections corresponding to the Holocene. The Dome C and Caroline DOC investigations include, for the first time, Antarctic ice samples which correspond to the Last Glacial Maximum (LGM).

Ice cores extracted from Summit (central Greenland) and NEEM (North Greenland) were investigated with the aim to extend the limited number of DOC data available from preindustrial Greenland ice (prior to this study, only the year 1020 AD had been documented by Preunkert et al. (2011), Table 2). In addition these samples permitted examination of the impact on the DOC levels of boreal forest fire plumes, which were shown to often occur in summer (Legrand et al., 1992; Legrand and De Angelis, 1996; Savarino and Legrand, 1998). In this way, six and nine years covering pre-industrial time were investigated in the NEEM and Summit ice, respectively. The ages of ice from the Summit and NEEM sites were estimated by Clausen et al. (1997) and Rasmussen et al. (2013), respectively.

To remove contamination present on the outer part of ice samples, we applied the procedure detailed by Preunkert et al. (2011), who developed a special glass device in which ice samples are washed with ultrapure water and melted afterwards. During sample melting, an inert gas atmosphere is maintained inside the glass device to prevent contact of the ice sample with the ambient air of the lab. The following procedure was applied in routine: after its storage for $1-2 \mathrm{~h}$ at $0^{\circ} \mathrm{C}$, the sample is rinsed with ultrapure water and then put in the glass device, which was filled with $400 \mathrm{~mL}$ ultrapure water. Then the glass device is emptied before $50 \%$ of the initial volume of ice was melted. After the complete melting of the remaining ice, the liquid sample is transferred into the Phoenix 8000. The blank of the decontamination procedure was found to be below the detection limit.

\subsection{Ancillary atmospheric data collected at Concordia}

In our further ice core discussions, we will consider siterelevant atmospheric information on the levels of organic gases and WSOC aerosol, the two key atmospheric fractions expected to contribute to the organic content of snow and ice. As seen in Table 3, respective information is already available for high-elevated Alpine sites and for Summit but remains limited to some organic gases like HCHO and light carboxylic acids at Concordia. Therefore, we here report WSOC aerosol levels observed in a year-round set of 51 high-volume filters (circular quartz filters, Gelman Pallflex Tissuquartz 2500QAT-UP, $15 \mathrm{~cm}$ diameter) collected at Concordia on 1 January 2011 and 12 January 2012. Sampling was achieved continuously at weekly resolution with a flow rate of $0.7 \mathrm{~m}^{3} \mathrm{STP} \mathrm{min}^{-1}$. To reduce contamination by organic material, quartz filters were pretreated by heating during over hours at $450^{\circ} \mathrm{C}$ in laboratory. After that, filters were wrapped in thermally treated and cleaned aluminum foil. A $10 \mathrm{~cm}^{2}$ piece of each filter was extracted with $12 \mathrm{~mL}$ ELGA ultrapure water in view to measure ions and DOC. To remove particulate organic matter, the samples were passed through a hydrophilic PTFE filter $(0.45 \mu \mathrm{m}$, Millex-LCR from Millipore) prior to analysis. Twelve filter blanks representing the sampling procedure (including the filtration prior the DOC analysis) were analysed. The mean blank value reaches $4 \pm 1 \mathrm{ng} \mathrm{m}^{-3} \mathrm{STP}$, and was subtracted from atmospheric sample concentrations. HULIS were measured on five selected winter and summer filters using a filter surface of $36 \mathrm{~cm}^{2}$ for each sample.

\section{Results and discussions}

\subsection{Presentation of data obtained in this study}

DOC (or TOC) data of snow and ice samples obtained in this work are summarized in Table 1 for Antarctica, and in Table 2 for Greenland and the Alps. Antarctic ice samples were not seasonally resolved, and values reported in Table 1 correspond to annual means. In contrast, all values reported for Greenland snow and ice layers from Summit and NEEM are seasonally resolved. As previously discussed in numerous publications (see Legrand and Mayewski, 1997, and references therein), the seasonality of major ions in Greenland ice exhibits a sodium maximum during the winter season, a calcium peak in spring, and a maximum of ammonium and nitrate in summer (see the examples reported in Figs. 1 and 2). As seen in Fig. 1, the ice layer located at the top of the Summit ice core section exhibits a large increase of the ammonium level. As for the first time discussed by Legrand et al. (1992) such ammonium events that are accompanied by a large formate increase are related to plumes of boreal forest fires that can reach the Greenland ice sheet in summer. Similarly, another forest fire event was detected in a NEEM ice 
Table 3. Air and snow concentrations of various species observed at Concordia, Summit, and Mt Blanc. Species include atmospheric gases ( $\mathrm{HCOOH}, \mathrm{CH}_{3} \mathrm{COOH}$, and $\mathrm{HCHO}$ ) and aerosol such as water-soluble organic carbon (WSOC), humic-like substances (HULIS), methanesulfonate $\left(\mathrm{CH}_{3} \mathrm{SO}_{3}^{-}\right)$, dicarboxylates, sulfate, ammonium, and sodium. For OC concentrations of snow, we also report (values in parentheses) the calculated WSOC* fraction (see Sect. 5).

\begin{tabular}{|c|c|c|c|c|c|c|}
\hline & \multicolumn{2}{|c|}{ Concordia (central Antarctica) } & \multicolumn{2}{|c|}{ Summit (central Greenland) } & \multicolumn{2}{|c|}{ Mt Blanc (French Alps) } \\
\hline & Air (annual) & Snow (annual) & Air (summer) & Snow (summer) & Air (summer) & Snow (summer) \\
\hline $\mathrm{HCOOH}$ & 43 pptv $\left(23 \mathrm{ngC} \mathrm{m}^{-3} \mathrm{STP}\right)^{\mathrm{b}}$ & $0.3 \mathrm{ppbC}^{\mathrm{a}}$ & 500 pptv $\left(268 \mathrm{ngC} \mathrm{m}^{-3} \mathrm{STP}\right)^{\mathrm{d}-\mathrm{e}}$ & $2.4 \mathrm{ppbC}^{\mathrm{k}}$ & $300 \mathrm{pptv}\left(160 \mathrm{ngC} \mathrm{m}^{-3} \mathrm{STP}\right)^{\mathrm{o}}$ & $49 \mathrm{ppbC}^{\mathrm{a}}$ \\
\hline $\mathrm{CH}_{3} \mathrm{COOH}$ & 27 pptv $\left(30 \mathrm{ngC} \mathrm{m}^{-3} \mathrm{STP}\right)^{\mathrm{b}}$ & $0.9 \mathrm{ppbC}^{\mathrm{a}}$ & 400 pptv $\left(430 \mathrm{ngC} \mathrm{m}^{-3} \mathrm{STP}\right)^{\mathrm{d}-\mathrm{e}}$ & $7.2 \mathrm{ppbC}^{\mathrm{k}}$ & $278 \mathrm{pptv}\left(300 \mathrm{ngC} \mathrm{m}^{-3} \mathrm{STP}\right)^{\mathrm{O}}$ & $8 \mathrm{ppbC}^{\mathrm{a}}$ \\
\hline $\mathrm{HCHO}$ & 50 pptv $\left(27 \mathrm{ngC} \mathrm{m}^{-3} \mathrm{STP}\right)^{\mathrm{c}}$ & $0.4 \mathrm{ppbC}^{\mathrm{a}}$ & 150 pptv $\left(80 \mathrm{ngC} \mathrm{m}^{-3} \mathrm{STP}\right)^{f}$ & $1.6 \mathrm{ppbC}^{\mathrm{l}}$ & 400 pptv $(215 \text { ngC STP })^{q-q}$ & $3.6 \mathrm{ppbC}^{\mathrm{a}}$ \\
\hline WSOC/OC & $13 \mathrm{ngC} \mathrm{m}^{-3} \mathrm{STP}^{\mathrm{a}}$ & $\begin{array}{l}\sim 15 \mathrm{ppbC}^{\mathrm{a}} \\
(13 \mathrm{ppbC})\end{array}$ & $77 \mathrm{ngC} \mathrm{m}^{-3} \mathrm{STP}^{\mathrm{g}}$ & $\begin{array}{l}55 \mathrm{ppbC}^{\mathrm{m}} \\
(44 \mathrm{ppbC})\end{array}$ & $150 \mathrm{ngC} \mathrm{m}^{-3} \mathrm{STP}^{\mathrm{r}}$ & $\begin{array}{l}270 \mathrm{ppbC}^{\mathrm{a}} \\
(209 \mathrm{ppbC})\end{array}$ \\
\hline HULIS & $1.6 \mathrm{ngCm}^{-3} \mathrm{STP}^{\mathrm{a}}$ & $2 \mathrm{ppbC}^{\mathrm{a}}$ & ND & ND & ND & $30 \mathrm{ppbC}^{\mathrm{a}}$ \\
\hline $\mathrm{CH}_{3} \mathrm{SO}_{3}^{-}$ & $8.5 \mathrm{ng}\left(1.1 \mathrm{ngC} \mathrm{m}^{-3} \mathrm{STP}\right)^{\mathrm{a}}$ & $1.3 \mathrm{ppbC}^{\mathrm{a}}$ & $5 \mathrm{ng}\left(0.6 \mathrm{ngC} \mathrm{m}^{-3} \mathrm{STP}\right)^{\mathrm{h}}$ & $0.3 \mathrm{ppbC}^{\mathrm{k}}$ & 0 & 0 \\
\hline Diacids & $0.3 \mathrm{ng}\left(0.08 \mathrm{ngC} \mathrm{m}^{-3} \mathrm{STP}\right)^{\mathrm{a}}$ & $0.05 \mathrm{ppbC}^{\mathrm{a}}$ & $<5\left(1.4 \mathrm{ngC} \mathrm{m}^{-3} \mathrm{STP}\right)^{\mathrm{i}}$ & $<0.8 \mathrm{ppbC}^{\mathrm{n}}$ & $20 \mathrm{ngC} \mathrm{m}^{-3} \mathrm{STP}^{\mathrm{r}}$ & $16 \mathrm{ppbC}^{\mathrm{a}}$ \\
\hline $\mathrm{SO}_{4}^{2-}$ & $55 \mathrm{ng} \mathrm{m}^{-3} \mathrm{STP}^{\mathrm{a}}$ & $53 \mathrm{ppb}^{\mathrm{a}}$ & $200 \mathrm{ng} \mathrm{m}^{-3} \mathrm{STP}^{\mathrm{h}}$ & $100-200 \mathrm{ppb}^{\mathrm{k}-\mathrm{m}}$ & $400 \mathrm{ng} \mathrm{m}^{-3} \mathrm{STP}^{\mathrm{O}}$ & $255 \mathrm{ppb}^{\mathrm{a}}$ \\
\hline $\mathrm{NH}_{4}^{+}$ & $3.2 \mathrm{ng} \mathrm{m}^{-3} \mathrm{STP}^{\mathrm{a}}$ & $2.6 \mathrm{ppb}^{\mathrm{a}}$ & $30 \mathrm{ng} \mathrm{m}^{-3}$ STPj $^{\mathrm{j}}$ & $10 \mathrm{ppb}^{\mathrm{k}}$ & $110 \mathrm{ng} \mathrm{m}^{-3} \mathrm{STP}^{\mathrm{o}}$ & $190 \mathrm{ppb}^{\mathrm{a}}$ \\
\hline
\end{tabular}

${ }^{a}$ This work, ${ }^{b}$ Legrand et al. (2012), ${ }^{c}$ Hutterli et al. (2004) (see also comments in Sect. 4.2), ${ }^{d}$ Dibb and Arsenault (2002), ${ }^{\mathrm{e}}$ De Angelis et al. (2012), ${ }^{\mathrm{f}}$ Jacobi et al. (2002),

${ }^{\mathrm{g}}$ Hagler et al. (2007b), ${ }^{\mathrm{h}}$ Jaffrezo et al. (1994), ${ }^{\mathrm{i}}$ Jaffrezo et al. (1998), ${ }^{\mathrm{j}}$ Silvente and Legrand (1993), ${ }^{\mathrm{k}}$ Legrand and Mayewski (1997), ${ }^{1}$ Hutterli et al. (1999), ${ }^{\mathrm{m}}$ Hagler et al. (2007a), ${ }^{\mathrm{n}}$ Legrand and De Angelis (1996), ${ }^{\mathrm{o}}$ Preunkert et al. (2007), $\mathrm{p}^{\mathrm{P}}$ Fried et al. (2008), ${ }^{\mathrm{q}}$ Kormann et al. (2003), and ${ }^{\mathrm{r}}$ Legrand et al. (2007b).

core layer located at $140.15 \mathrm{~m}$ depth (see Fig. 2 and discussions in Sect. 6.2).

\subsection{A critical discussion on data inconsistencies}

As seen in Table 1, DOC (or TOC) concentrations widely fluctuate from site to site and from very recent snow to old ice, the range being particularly large for Antarctic samples (from less than $5 \mathrm{ppbC}$ up to $900 \mathrm{ppbC}$, Table 1). Prior our shallow snow study conducted at Concordia, data tended to suggest that $\mathrm{OC}$ is more abundant in the recent snow layers than in ice. Since this tendency is even more pronounced in Antarctica than in Greenland data, we can clearly rule out the assumption of a trend due to anthropogenic emissions. If correct, these high OC contents of Antarctic and Greenland surface snow with respect to deeper layers would suggest a very strong loss of volatile organic carbon after snow deposition. However, as shown in Table 1, our surface snow study at Concordia conflicts with this assumption.

Regarding existing surface snow Summit data, we may ask whether the higher OC values reported by Grannas et al. (2004) (400-580 ppbC of TOC, Table 2) compared to those reported by Hagler et al. (2007a) (111 $\pm 45 \mathrm{ppbC}$ of DOC, Table 2) are partly due to the use of a combustion method thought to be far more efficient than any UV oxidation method to oxidize insoluble organic particles possibly present in samples. In addition, Table 1 indicates that the highest values reported for Antarctic surface snow at the South Pole and in margin area of Dronning Maud Land and Princess Elizabeth Land were also obtained using a combustion method (instead of the UV method we deployed for surface snow and snow pit samples collected at Concordia). Therefore we will discuss in the next section to what extent the use of different (UV oxidation versus combustion) methods may have induced some differences in the results. Finally, given the high risk of sample contamination, especially for porous material like snow or firn (see Sect. 2.3.1), we will carefully revisit the respective precautions undertaken in the different studies to minimize contamination during sampling and analysis.

\subsubsection{TOC or DOC?}

When directly applied to liquid samples, combustion methods are thought to efficiently oxidize water-soluble species as well as insoluble organic particles present in samples, and thus OC data obtained with this method (see Tables 1 and 2) would refer to the TOC content of the respective samples. In contrast, it is generally accepted that the UV-induced oxidation methods give rather low recoveries on particulate organic matter (Booth et al., 1998), especially for samples containing a high particulate organic content. Since the recoveries are, however, not zero, OC determinations obtained with a UV method are only referred to as DOC if a sample filtration through a quartz fibre filter was applied prior to OC measurements. Whereas this procedure was applied by Hagler et al. (2007a), all the other studies using UV methods (Federer et al., 2008; Twickler et al., 1986; Preunkert et al., 2011; Legrand et al., 2007a, 2013) do not remove insoluble particles prior $\mathrm{OC}$ analysis.

If the water-insoluble organic fraction (WinOC) of sample is large with respect to the one of water-soluble organic species, the direct use of a UV method without sample filtering would partly account for the above-discussed discrepancies. However, at the very remote places that we discuss here, insoluble organic carbon is not expected to dominate the organic carbon budget. As an example, the contribution of WinOC retained by filtering the samples through quartz filters has been documented for summer snow samples at Summit (Hagler et al., 2007a), showing, on average, a WinOC / DOC ratio close to $10 \%$ at that site. Given this low WinOC contribution, it is even possible that UV methods 
applied without sample filtering are able to partly (or totally) oxidize the particulate matter present in this kind of samples.

Federer et al. (2008) compared their UV method with a Sievers 900 TOC analyser, and reported a mean value of $145 \mathrm{ppbC}$ measured with their UV system compared to $155 \mathrm{ppbC}$ with the Sievers analyser in a melted ice sample from Dye-3 (South Greenland). Given the certified blank for the Sievers vial $(10 \mathrm{ppbC})$ the authors concluded that the difference between the two results is not significant. Using a hydrophilic PTFE filter $(0.45 \mu \mathrm{m}$, Millex-LCR from Millipore) to remove particulate organic matter from samples, the authors filtered another melted ice sample from Dye-3. This time the unfiltered sample revealed an OC content of $204 \mathrm{ppbC}$ compared to $190 \mathrm{ppbC}$ measured in the filtered sample, which lead the authors to suggest that their UV method measures TOC rather than DOC in samples containing a small amount of insoluble organic matter. In addition, their results suggest that particulate organic content of precipitation at remote sites such as Greenland contributes a minor fraction to the total organic content. Attempts made by Preunkert et al. (2011) to quantify the recovery of their method for particulate carbon of melted ice samples were unsuccessful due to contamination occurring during sample filtering. Preunkert et al. (2011) therefore reported their data as dissolved organic (DOC) rather than total organic (TOC) carbon. However, at least for samples from Greenland and Antarctica, the above discussions tend to suggest that UV methods oxidize most insoluble matter at these sites. Thus, Antarctic and Greenland OC values obtained with a UV method without sample filtering reported in Tables 1 and 2 may correspond to values of TOC. They may represent an overestimation by some $10 \%$ if compared for instance with the Greenland DOC data from Hagler et al. (2007a). Therefore, within an uncertainty of $10 \%$, Antarctic and Greenland OC values obtained with a UV method without sample filtering can be referred to either as TOC or as DOC.

For the high-Alpine site of Col du Dôme, Legrand et al. (2007a) reported a mean WinOC/DOC ratio of $20 \%$ instead of the $10 \%$ found at Summit. To get a more quantitative idea of the WinOC recovery of the UV method from Preunkert et al. (2011) for this site, the sample-filtering method was improved, and one of the 2011 summer snow layers collected at the Col du Dôme site (see Sect. 2.3.1) was measured before and after sample filtering with a hydrophilic PTFE filter $(0.45 \mu \mathrm{m})$. A filtration blank was analysed in parallel, indicating an OC contamination of $84 \mathrm{ppbC}$. The unfiltered sample revealed an OC content of $664 \mathrm{ppbC}$ versus $718 \mathrm{ppbC}$ measured on the filtered sample. These values suggest that around $30 \mathrm{ppbC}$ of WinOC were detected by the UV method in the unfiltered sample. If a WinOC / DOC ratio of $20 \%$ is assumed for this site (see above), a WinOC content in the range of $120 \mathrm{ppbC}$ would be expected, suggesting that only one-quarter of the insoluble matter was oxidized by the UV method of Preunkert et al. (2011) in this Alpine sample.
In conclusion, whereas Antarctic and Greenland OC values obtained with a UV method without sample filtering reported in Tables 1 and 2 may correspond to TOC, the Alpine OC values reported in Table 2 correspond to DOC rather than TOC.

\subsubsection{Sample contamination}

Since the inconsistencies seen on the DOC (TOC) content of samples from Greenland and Antarctica largely exceed $100 \%$, and thus cannot be explained with the presence of insoluble organic matter (see Sect. 3.2.1), we revisit data reported in Table 1 and 2 with regard to potential contamination problems. Focusing the discussion on Antarctica, where the inconsistencies are larger than elsewhere, levels reported for the South Pole and margin areas of Dronning Maud Land and Princess Elizabeth Land are at least one order of magnitude higher than those obtained in this study for Concordia. The sampling of surface snow carried out at the South Pole was not dedicated to detailed investigation of TOC, and snow was collected and stored in Whirl-Pak polyethylene bags (Grannas et al., 2004). As previously discussed by Preunkert et al. (2011), one should avoid plastic devices to collect snow when dealing with very low OC level as a few tens of ppbC or less. Grannas et al. (2004) also reported TOC values covering the preceding year of snow sampling at Summit. Here values can be compared to those obtained in another study more focused on DOC and carried out with more stringent sampling conditions (Hagler et al., 2007a). Indeed, in this latter study focused on DOC, snow was sampled with airtight glass bottles previously cleaned in ultrapure water and heated to $550^{\circ} \mathrm{C}$ for $12 \mathrm{~h}$. As seen in Table 2, the snow samples collected at Summit in plastic bags exhibit far higher values than those collected into precleaned glass bottles. Thus it is very likely that the near-surface snow collected in plastic bags at the South Pole (Grannas et al., 2004) was also contaminated. Surface snow samples from Dronning Maud Land (DML) and Princess Elizabeth Land also indicate high TOC levels (260 ppbC for PEL, $140 \mathrm{ppbC}$ for DML) that were attributed to marine emissions (Antony et al., 2011). As discussed in Sect. 6.1, such an importance of the ocean as a source of OC aerosol appears far less well established than sometimes previously proposed. Furthermore, an alternative explanation may be that the sampling made with a polypropylene scoop and storage in sealed low-density polyethylene bags has caused contamination of samples. It has here to be emphasized that the dust content observed in these samples (Coulter counter measurements) appears also rather high, reaching for instance 400 to $2000 \mathrm{ppb}$ in the DML transect compared to the mean value of $30 \mathrm{ppb}$ observed in the Holocene ice at DML (Ruth et al., 2008).

Other available Antarctic data reported in Table 1 concern ice. Here, $\mathrm{OC}$ values are consistently in the range of $10 \mathrm{ppbC}$ at all Antarctic sites except those from Talos Dome, which indicate values from one to several hundreds of ppbC. The 
proximity of the ocean to this site compared to the case of sites located above $3000 \mathrm{~m}$ elevation does not seem to be the cause of these high levels. Indeed, as seen in Table 1, the ice section from the Caroline site originating from a $1300 \mathrm{~m}$ elevation area still indicates a mean $\mathrm{OC}$ value as low as $11 \mathrm{ppbC}$. Unexpectedly, the Talos Dome OC values exceed even those observed in pre-industrial ice from Greenland, a region located far closer to strong emissions of various organic compounds from the continental biosphere. The particularity of the Talos Dome ice samples lies in the fact that the corresponding ice was extracted by using a drill fluid, whereas other data were obtained from ice cores extracted by dry drilling. In addition, OC sampling of the Talos Dome ice was done continuously by applying a melting head on the ice (Federer et al., 2008). From our experience, OC measurements are very sensitive to the presence of cracks in the ice, especially when a fluid was used for the drilling. For instance, one of the three NEEM ice sections $(186.6 \mathrm{~m}$ depth, Table 2) was damaged, having a visible inner crack. Although having cleaned it with the same procedure as the other NEEM ice sections, the three pieces of ice from this section clearly indicated a huge remaining contamination (mean value of $570 \pm 50 \mathrm{ppbC}$ ), and required subsequent intensive rinsing of the glass-melting device over several days to recover typical blank levels. From that it can be supposed that the melting head used for the ice decontamination had either crossed existing micro-cracks or induced the formation of new ones, which allowed for penetration of drilling liquid into the Talos Dome OC samples. It is also interesting to examine OC measurements made on ice from the $905 \mathrm{~m}$ long Dome $\mathrm{C}$ ice core that contains cracks but was extracted in 1978 using a thermal drill but without fluid. As seen in Table 1, in spite of the presence of cracks, OC values observed in this kind of ice remain fairly close to $10 \mathrm{ppbC}$, suggesting that cracks that efficiently re-closed rapidly after the core extraction limited any subsequent contamination during storage of ice cores.

\section{Towards a more comprehensive picture of the $\mathrm{OC}$ content of snow and ice}

Several points emerge from the above discussions on existing inconsistencies in the OC (DOC and TOC) literature data. It has to be noted that the differences related to the insoluble OC recoveries of the deployed (UV versus combustion) methods cannot account for observed large inconsistencies in the Greenland and Antarctic data. Instead, the inconsistencies highlighted in Tables 1 and 2 seem to be often related to contamination problems during sampling and storage of snow, as well as to the ice quality and/or its degradation (i.e. formation of cracks) during the subsampling.

Discarding values obtained in snow sampled into plastic bags or stored in not properly closed glass bottles, an OC (DOC or TOC within $10 \%$ uncertainty) concentration of around $10-15 \mathrm{ppbC}$ seems to be a typical value for Antarctic surface snow (Table 1). With the single exception of Talos Dome, most DOC concentrations observed in goodquality Holocene ice range between 5 and $10 \mathrm{ppbC}$. Such a rather low abundance of organic carbon in Antarctica apparently conflicts with data reported by Calace et al. (2005), who reported from 52 to $92 \mathrm{ppb}$ of dissolved fulvic acid in snow pit samples collected at Concordia. Indeed, if correct, such an abundance of the fulvic acid would imply the presence of at least 26-46 ppbC of DOC in Concordia snow. As shown in Table 3, our HULIS measurements made in several snow samples collected at Concordia indicate, however, far lower concentrations (from 1 to $3 \mathrm{ppbC}$ ). Note also that DOC values observed in the Holocene ice indicate values close to $5 \mathrm{ppbC}$ at Vostok and slightly higher ones in Caroline ice $(\sim 10 \mathrm{ppbC})$ corresponding to precipitation deposited initially between 1320 and $1550 \mathrm{~m}$ elevation. More data are, however, needed in order to increase the significance of such a difference and to discuss a possible contribution of the Antarctic Ocean to the budget of organics in Antarctic snow (see also further discussions in Sect. 6.1).

As done for Antarctica, the consistency of the various OC data gained in Greenland is examined after having excluded the ones obtained from snow sampled into plastic bags (Table 2). Annual mean values observed within this study in 60 pre-industrial Summit ice samples that were not influenced by biomass burning inputs (see Sect. 3.1) are close to $12 \pm 7 \mathrm{ppbC}$. These values are consistent with the more limited Summit data set (10 samples) reported by Preunkert et al. (2011) $(23 \pm 11 \mathrm{ppbC})$. A similar range is observed in the NEEM pre-industrial ice $(19 \pm 7 \mathrm{ppbC}$, Table 2$)$. Over the more recent years (2002-2005) at Summit, Hagler et al. (2007a) reported a mean annual DOC value of $40 \mathrm{ppbC}$ (i.e., at least twice higher than the pre-industrial level). As further discussed in Sect. 6.2, this difference may be attributed to anthropogenic activities. In addition, the latter study reported also a mean DOC value close to $110 \mathrm{ppbC}$ for the 2006 surface summer snow at Summit (Table 2). As discussed by Anderson et al. (2008), it seems that most postdepositional OC effects at that site are due to formic and acetic acid re-emission from the snowpack. Since this surface summer value is twice higher than the mean one observed over the four previous summers, significant post depositional effects likely occurred at that site. Recent $O C$ values observed at Summit are in the lower limit of the OC range reported for the years of 1982-1984 at Dye-3 (30 ppbC in winter and $320 \mathrm{ppbC}$ in summer, Twickler et al., 1986). As already discussed by Hagler et al. (2007a), this may be related to the different location (South Greenland vs. central Greenland) and elevation ( $2486 \mathrm{~m}$ vs. $3240 \mathrm{~m}$ ) of the two sites.

In the Alps, the different data set consistently show annual mean values close to $70 \mathrm{ppbC}$ prior to World War II (from 1925 to 1936$)$ and higher ones (145 ppbC) over the recent decades (Table 2). Finally, the study of upper surface snow layers indicates a mean annual value of $140 \mathrm{ppbC}$, suggesting 
no systematic difference compared to the DOC levels observed in ice layers corresponding the late 1980s (i.e. corresponding to the youngest ice layers located just below the close-off).

\section{The OC snow chemical speciation}

The OC content of snow deposits is related to OC aerosols as well as organic gases present in the atmosphere that have been trapped in precipitation. In order to reconstruct relevant information on past change of atmospheric aerosol, it is necessary to evaluate which fraction of $\mathrm{OC}$ in ice can be attributed to either OC aerosol or organic gases. Among shortchain organic gases present in the atmosphere, those having a strong polar character like monocarboxylic acids, alcohols, aldehydes, and ketones can be incorporated in snow and ice and significantly contribute to the OC ice level.

Using data summarized in Table 3, we compare in Fig. 3 the chemical composition of OC present in recent snow layers deposited at Concordia (annual), Summit (summer), and in the Alps (summer). The choice of annual values for Antarctica and summer values for the two other sites is related to the possibility to compare, at each site, air and snow concentrations over the same seasonal interval. Year-round atmospheric data are available at Concordia, but the low snow accumulation rate at that site prevents seasonal atmospheric parameters being well archived in snow. Conversely, seasonally resolved snow records that are available at Summit and in the Alps can only be compared to atmospheric observations for summer since most atmospheric observations are available for that season. In all three cases, chemical measurements included species related to organic gases (monocarboxylic acids and HCHO). Concerning the aerosol fraction, in addition to dicarboxylic acids and methanesulfonic acid that were documented in snow at the three sites, HULIS were determined in the Alps and in Antarctica but not yet in Greenland.

As discussed by Legrand et al. (2013), given their atmospheric abundance and high effective Henry's law constants, formic and acetic acids and, to a lesser extent, formaldehyde are organic gases that may be significantly incorporated in ice. In the case of the Alps, the authors concluded that $\mathrm{C}_{1}-\mathrm{C}_{3}$ mono-carboxylic acids and $\mathrm{HCHO}$ represent the most important water-soluble organic gases contributing to the DOC content of ice (mean annual contribution ranging from $34 \%$ over the years $1971-1988$ to $43 \%$ over the years 1921-1951). The remaining DOC amount present in ice denoted WSOC $^{*}$ and calculated as $\left[\mathrm{WSOC}^{*}\right]=[\mathrm{DOC}]$ - [Monoacid-C] $-[\mathrm{HCHO}-\mathrm{C}]$ would correspond to WSOC aerosol. Of this ${\text { WSOC* quantity, the authors identified } \mathrm{C}_{2}-}^{-}$ $\mathrm{C}_{5}$ dicarboxylic acids and HULIS, but a large fraction remained chemically unidentified (i.e. 30 and $45 \%$ of DOC over the 1921-1951 and 1971-1988 time periods, respectively). As seen in Fig. 3, the unknown fraction of recent

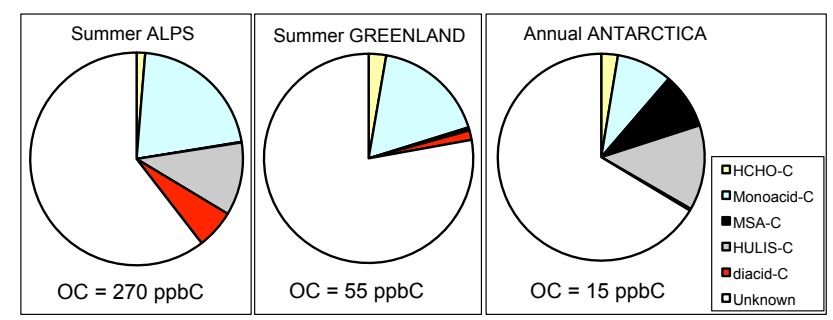

Fig. 3. From left to right: chemical composition of OC present in recent summer snow layers at the Col du Dôme and Summit sites, and in recent annual snow layers at Concordia (see Sect. 4). Here, OC values refer to DOC at Col du Dôme, DOC, or TOC within $10 \%$ uncertainty in Greenland and Antarctica (see Sect. 3.2.1). The identified organic species include formaldehyde, $\mathrm{C}_{1}-\mathrm{C}_{3}$ monocarboxylic (formic, lactic, acetic, glycolic, and glyoxylic) acids, MSA, $\mathrm{C}_{2}-\mathrm{C}_{5}$ dicarboxylic (oxalic, malic, malonic, succinic, and glutaric) acids, HULIS, and the remaining unidentified fraction of OC (see Sect. 4).

Alpine summer snow layers accounts for $60 \%$ of DOC instead of $44 \%$ over the years $1971-1988$ and $27 \%$ over the years 1921-1951 (Legrand et al., 2013). Though based on a single summer value (2012), the increasing trend of the unknown fraction from prior to until after World War II revealed by Legrand et al. (2013) (see further discussions in the Sect. 6.2) seems to continue from the late 1980s to very recent years.

The most extended OC speciation available for Greenland summer snow deposits is reported in Fig. 3 but does not yet include HULIS. Whereas $\mathrm{C}_{1}-\mathrm{C}_{3}$ mono-carboxylic acids and $\mathrm{HCHO}$ contribute together for some $20 \%$ of OC, the other chemically identified fraction (MSA plus diacids) remains very weak (2\%) instead of $17 \%$ (HULIS plus diacids) in the Alps. Note that, as expected but in contrast to the Alps, a small organic aerosol fraction is related to the presence of methanesulfonate in Greenland. Finally, Fig. 3 reports for the first time the OC speciation of Antarctic snow. Compared to the other sites, $\mathrm{C}_{1}-\mathrm{C}_{3}$ mono-carboxylic acids and HCHO represent a weaker contribution (11\% of OC). In addition, not only MSA but also HULIS represents a significant fraction of WSOC at that very remote site. The conclusion drawn for the case of the Alps that $\mathrm{C}_{1}-\mathrm{C}_{3}$ monocarboxylic acids and $\mathrm{HCHO}$ represent the most important water-soluble organic gases contributing to the OC content of ice, and that consequently the $\mathrm{WSOC}^{*}$ quantity corresponds to WSOC aerosol, remains likely also true for Greenland and Antarctica except if oceans surrounding the Greenland and Antarctic ice caps emit other water-soluble organic gases than monocarboxylic acids and/or formaldehyde. One possible candidate is dimethylsulfoxide (DMSO), a watersoluble gas produced by the DMS/OH oxidation via the addition channel that is particularly efficient at low temperatures. Typical concentrations of $3 \mathrm{ngC} \mathrm{m}^{-3}$ STP of DMSO, which sporadically reach $20 \mathrm{ngC} \mathrm{m}^{-3} \mathrm{STP}$, were observed 
in summer at coastal Antarctica by Jourdain and Legrand (2001). However, as discussed by Legrand et al. (2001), once trapped in the liquid phase (cloud or hydrated aerosol), DMSO is quickly oxidized into MSA. Therefore the oxidation by-products from DMS emitted by the ocean at high latitudes contribute rather to the WSOC* aerosol fraction (via MSA) than to the fraction related to water-soluble organic gases. In the following we assume therefore that the WSOC* quantity calculated as [DOC] - [Monoacid-C] $-[\mathrm{HCHO}-\mathrm{C}]$ would correspond to WSOC aerosol fraction in Greenland and Antarctic snow and ice.

\section{Atmospheric implications}

In this section we will discuss to what extent the observed spatial variations of the DOC ice contents are consistent with our present knowledge of organics in the atmosphere. After that, we will initiate a discussion on the origins and potential atmospheric implications of some observed temporal changes detected in Antarctica, Greenland, and the Alps over various timescales, i.e. from present-day seasonal variations to changes during the last glacial-interglacial period.

\subsection{Spatial change: Antarctica versus Greenland and the Alps}

As concluded above, a comprehensive picture on the DOC content of pre-industrial ice reveals a typical annual mean level of $\sim 5-10 \mathrm{ppbC}$ in Antarctica, $20 \mathrm{ppbC}$ in Greenland, and $70 \mathrm{ppbC}$ in the Alps. To highlight the origins of these spatial variations, air and snow concentrations of organic gases suspected to contribute to the DOC content of snow, and of various aerosols including those contributing to the WSOC fraction as well as a few well-known inorganic backup species like sulfate or ammonium, are compared in Table 3. Of course, this comparison only considers snow layers deposited over very recent times during which atmospheric observations are available. Though the OC level in the Alps and in Greenland seems to increase by a factor of 2 over the 20th century (see further discussions in Sect. 6.2), Table 3 still permits identification of the main cause driving the increase of the pre-industrial OC level in ice from Antarctica to Greenland and from Greenland to the Alps.

Table 3 suggests that the increase of the DOC content from Antarctic to Greenland (from 5-10 to $20 \mathrm{ppbC}$ ) and from Greenland to Alpine (from 20 to $70 \mathrm{ppbC}$ ) pre-industrial ice is related to an increase of aerosol and to a lesser extent of water-soluble gases. As seen in Table 3, water-soluble organic gases are more abundant in the Alps than in Greenland, and in Greenland than in Antarctica, the change being particularly large for monocarboxylates. For instance, in surface snow, the amount of monocarboxylates increases from $\sim 1.2 \mathrm{ppbC}$ (annual mean) in Antarctica to $10 \mathrm{ppbC}$ (summer) in Greenland, and further to $\sim 60 \mathrm{ppbC}$ (summer) in the Alps. Due to the various parameters and complexity of involved processes that control the atmospheric budget of carboxylic acids over snow-covered regions, a discussion on these geographical differences is complex and clearly out of the scope of the present paper. First, while measurements made at Col du Dôme are likely representative of the free European troposphere, this is not the case in Greenland and Antarctica, where stable, thin atmospheric boundary layers often develop. Second, atmospheric gases like $\mathrm{HCOOH}$ and $\mathrm{CH}_{3} \mathrm{COOH}$ are weak acids, for which incorporation in precipitation strongly depends on cloud $\mathrm{pH}$ and cloud water liquid content. Third, at least in Greenland, snow emissions are suspected to strongly control atmospheric concentrations observed in the very stable lowermost atmosphere lying over this ice cap (Dibb and Arsenault, 2002). One consideration that will be relevant in further discussions of these species is the fact that, in the present-day atmosphere, they are mainly secondarily produced from biogenic precursors mainly emitted by the continental biosphere (Paulot et al., 2011). The weak contribution of anthropogenic sources to the budget of monocarboxylic acids was also supported by the examination of their long-term ice core trends in Greenland (Legrand and De Angelis, 1996) and in the Alps (Legrand et al., 2003).

The main cause leading to the observed increase of the DOC content from Antarctic to Greenland and from Greenland to the Alpine pre-industrial ice is related to an increase of the WSOC* fraction. Using concentrations of monocarboxylic acids and $\mathrm{HCHO}$ reported in Table 3, we calculate that in surface snow WSOC $^{*}$ increases from $\sim 13$ ppbC (annual mean) in Antarctica to $44 \mathrm{ppbC}$ (summer) in Greenland and further to $\sim 210 \mathrm{ppbC}$ (summer) in the Alps. To relate these snow values with atmospheric observations we also compare snow and air concentrations of sulfate and ammonium at the three sites. At Concordia, sulfate and ammonium data suggest that $1 \mathrm{~g}$ of snow roughly contains the amount of aerosol present in $1 \mathrm{~m}^{3} \mathrm{STP}$ of air. The $13 \mathrm{ppbC}$ of WSOC $^{*}$ found in Concordia surface snow are consistent with the WSOC level observed in the atmosphere (annual mean of $13 \mathrm{ngC} \mathrm{m}^{-3}$ STP). At Summit, sulfate and ammonium data suggest that, in summer, $1 \mathrm{~g}$ of snow roughly contains the amount of aerosol present in $0.5 \pm 0.2 \mathrm{~m}^{3} \mathrm{STP}$ of air. In this way, the $44 \mathrm{ppbC}$ of $\mathrm{WSOC}^{*}$ found in Greenland summer snow are consistent with the WSOC level observed in the atmosphere (summer mean of $77 \mathrm{ngC} \mathrm{m}^{-3} \mathrm{STP}$ ). In contrast to the case of Antarctica and Greenland, for which surface snow and atmospheric measurements cover roughly the same time periods, values reported for atmospheric aerosols for the Alps were obtained in summer 2004 by Legrand et al. (2007b) and Preunkert et al. (2007), whereas summer snow concentrations cover the 2012 summer. Considering the recent decreasing trend of sulfate over Europe and, reversely, the increasing trend of WSOC (see Preunkert and Legrand, 2013), the preceding exercise done for Greenland and Antarctica may be less accurate in the case of the Alps. Nevertheless, as seen in Table 3, the 209 ppbC of WSOC* found in Alpine summer 
snow in 2012 are consistent with the WSOC level observed in the summer atmosphere 2004 ( $\left.150 \mathrm{ngC} \mathrm{m}^{-3} \mathrm{STP}\right)$. It therefore appears that the spatial change of the calculated WSOC* present in snow consistently follows the increase of WSOC concentration in the present atmosphere seen between central Antarctica, central Greenland, and the Alps.

Such spatial changes are consistent with present-day observations made over continents and oceans. For instance, a two-year-round climatology of organic aerosols was conducted at six sites located along a west-east transect extending from the Azores in the mid-Atlantic Ocean to K-Puszta (Hungary) in central Europe by Pio et al. (2007). Here, it was shown that $\mathrm{OC}$ aerosol is more than 10 times less abundant at the oceanic site of Azores ( $380 \mathrm{ngC} \mathrm{m}^{-3}$ STP) than over the European continent ( $4900 \mathrm{ngC} \mathrm{m}^{-3}$ STP at K-Puszta, and $3400 \mathrm{ngC} \mathrm{m}^{-3}$ STP at Schauinsland in the Black Forest, Germany). Although being far weaker than continental sources, the marine source still may represent a source of OC aerosol for Antarctica, as proposed by Calace et al. (2005) and Antony et al. (2011). However, even in the marine boundary layer, the importance of emissions of organic aerosol is still the subject of debate (see the recent review from Gantt and Meskhidze, 2013). With respect to global sea-salt emission reaching $1000 \mathrm{Tg} \mathrm{yr}^{-1}$ (Eriksson, 1959), the global emission of submicron marine $\mathrm{OC}$ aerosol averaged $10 \mathrm{Tg} \mathrm{yr}^{-1}$ with a range of one order of magnitude depending on the studies, locations, and proximity of biologically productive waters. To date, the unique study from Zorn et al. (2008) carried out in summer marine Antarctic air masses reported only $20 \mathrm{ng} \mathrm{m}^{-3}$ of OC compared to $40 \mathrm{ng} \mathrm{m}^{-3}$ of MSA and $310 \mathrm{ng} \mathrm{m}^{-3}$ of sulfate in the submicron fraction of aerosol. Further work is needed to evaluate the role of marine emissions on the OC budget of Antarctic aerosol.

\subsection{Temporal changes}

Preliminary discussions on the causes of some observed temporal changes including seasonal variations, the possible trend from the pre-industrial to the present-day atmosphere, and the response to natural events such as sporadic arrival of forest fire plumes or climatic variations (last glacialinterglacial transition) are here presented.

Starting with Antarctic data, where the too low snow accumulation prevents good preservation of the seasonal cycle, year-round atmospheric samplings made at Concordia in 2011 (Fig. 4) reveal a weak maximum of WSOC aerosol levels in summer. Note that this contrasts with the rather strong summer maximum observed for sulfate and methanesulfonate in relation to strengthened marine biogenic DMS emissions from the Antarctic oceans of that season (Preunkert et al., 2008). Also, the WSOC seasonality differs from the one of sodium, which shows higher levels during the second half of winter 2011 than in summer. The species that seems to mimic the WSOC seasonality the best is the one of mineral dust emitted by continents and hereafter long-range transported towards Antarctica. Mineral dust was found to be twice more abundant in summer than in winter in Antarctica (Wagenbach, 1996). In this way, the seasonality of WSOC in Antarctica is consistent with a large dominance of WSOC aerosol sources over continents rather than oceans. In Greenland ice, the DOC level is also generally characterized by a summer maximum (with the noticeable exception seen in Fig. 1 for 1299 AD). Not enough data are, however, available to separate spring and summer, two seasons during which the origin of air masses are different (Arctic Basin in spring, and North America in summer). Finally, in the Alps, the seasonal cycle of WSOC* $^{*}$ characterized by a summer maximum was discussed by Legrand et al. (2013), showing that wood burning may represent the main source in winter, whereas vegetation emissions represent the dominant source in summer.

Data available in Greenland and in the Alps indicate a significant increase of $\mathrm{OC}$ concentrations from the preindustrial era to the recent years. In Greenland, the 15 investigated pre-industrial years (Table 2) indicate winter levels below $10 \mathrm{ppbC}$ and summer levels ranging between 20 and $40 \mathrm{ppbC}$. Compared to the four recent years investigated by Hagler et al. (2007a) at Summit (20 ppbC in winter and $55 \mathrm{ppbC}$ in summer, Table 2), these pre-industrial Greenland values are slightly lower. In the Alpine ice, the DOC levels increased by a factor of 2-3 in winter and summer from the 1921-1951 years to the 1971-1988 years (Table 2). The summer and winter levels observed in pit samples covering the year 2012 remain similar to those observed over the years 1971-1988 (Table 2), which tends to suggest that no significant increase had occurred between the 1980s and the present. Note that even limited to the year 2012, these data seem to be representative of the very recent time period. Indeed, the mean 2012 summer levels of sulfate ( $350 \mathrm{ppb})$, nitrate $(380 \mathrm{ppb})$, and ammonium (144 ppb) are very similar to corresponding typical levels detected in the middle of the $2000 \mathrm{~s}$ ( $300 \mathrm{ppb}$ of sulfate, $370 \mathrm{ppb}$ of nitrate, and $145 \mathrm{ppb}$ of ammonium, Preunkert and Legrand, 2013).

At both sites, the DOC increase over time remains close to a factor of 2 and is mainly related to the $\mathrm{WSOC}^{*}$ fraction. This change is rather moderate compared to the corresponding ones previously revealed for sulfate aerosol in response to growing $\mathrm{SO}_{2}$ emissions in the Northern Hemisphere over the 20th century (see a more detailed discussion in Preunkert and Legrand, 2013). In the case of the Alps, the ${ }^{14} \mathrm{C}$ signature of the DOC content of summer ice revealed that, in spite of this increase, at least $75 \%$ of DOC is of biogenic origin (May et al., 2013). Furthermore, the summer $\mathrm{WSOC}^{*}$ change was highlighted by examining the time lag of the $\mathrm{DO}^{14} \mathrm{C}$ in ice with the ${ }^{14} \mathrm{CO}_{2}$ around the bomb peak of 1965 , the authors clearly concluded that the main biogenic source contributing to the DOC in ice in summer is the living biosphere, while biomass burning represents a very weak source. There are many possible causes that may have strengthened either biogenic precursors of atmospheric WSOC (e.g. increasing temperature and or higher 


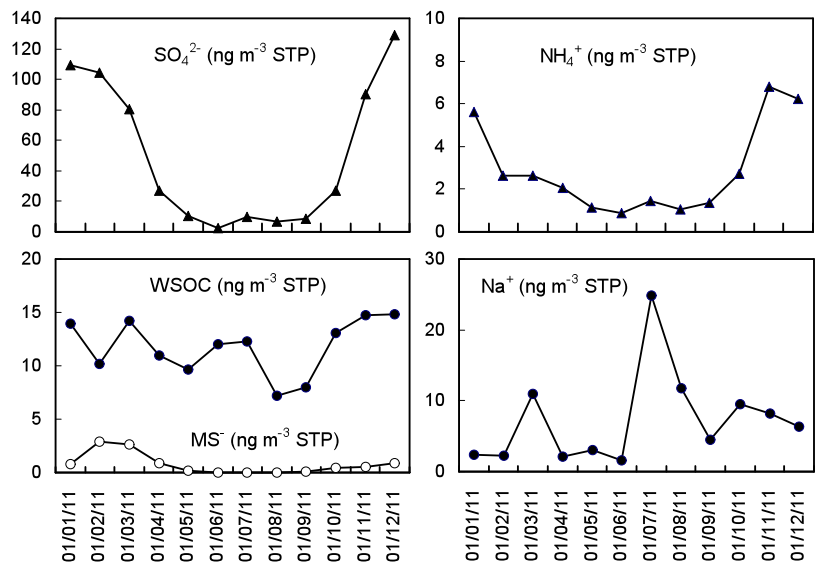

Fig. 4. Year-round bulk aerosol composition observed at Concordia in 2011. Note the higher sodium values in winter than in summer and the well-marked maximum of sulfate and $\mathrm{MS}^{-}\left(\mathrm{CH}_{3} \mathrm{SO}_{3}^{-}\right)$in summer (see discussions in Sect. 6.2).

atmospheric $\mathrm{CO}_{2}$ level) or the gas-particle conversion rate (e.g. increasing ozone concentrations). However, since most of the WSOC* fraction change was found to be related to an increase of the chemically unidentified fraction of DOC, it is difficult at this stage to discuss further the causes of these changes.

Our Greenland study documents for the first time the DOC content together with its speciation along forest fire events (Figs. 1 and 2). The pioneer study from Legrand et al. (1992) has already revealed an input of formate in such events. Here, we can extend the examination of the organic composition of such perturbation. As seen in Fig. 2, it appears that the main contributors to the increase of DOC along such events are monocarboxylates (77\%) mainly as formate, chemically unidentified species (20\%), and to a lesser extent dicarboxylates $(2 \%)$ mainly as oxalate and $\mathrm{HCHO}(1 \%)$. We have to point out here that, in contrast to background formate levels that are likely present in the form of formic acid, the formate observed along with forest fire events is present in the form of ammonium formate aerosol. As discussed in Sect. 5, the HULIS level has not yet been documented in Greenland snow and ice. These species may account for the unknown contribution in forest fire events since they are known to be formed during incomplete breakdown of polymeric plant matter (Mayol-Bracero et al., 2002).

Finally, as seen in Table 1, though being still limited to a few samples, the Antarctic data gained on the Caroline ice core suggest a significant decreasing level of OC during the Ice Age compared to the Holocene. Note that, although probably slightly contaminated due the presence of cracks (see Sect. 3.2.2), the Dome $\mathrm{C}$ data also tend to suggest lower levels during Ice Age than during the Holocene. One possible cause for this decrease during the Ice Age would be the lowering of continental biogenic emission (vegetation) following colder and drier conditions.

\section{Conclusions and perspectives}

Available data on the dissolved (or total) organic carbon content of snow and ice from Antarctic, Greenland, and Alpine ice cores were critically reviewed to understand the causes of existing inconsistencies. Most of the large inconsistencies were found to be related to contamination problems during sampling and storage of snow, as well as degradation of the ice quality (presence of cracks), rather than to the different recovery of deployed (UV versus combustion) methods in oxidizing insoluble OC material present in samples. Discarding outliers from data, a more consistent picture with respect to our knowledge of OC sources, which are predominantly present over continents, emerges. For instance, the typical annual pre-industrial DOC ice content is close to $\sim 5-10 \mathrm{ppbC}$ in Antarctica, $20 \mathrm{ppbC}$ in Greenland, and $70 \mathrm{ppbC}$ in the Alps. The investigation of chemical organic species present in snow and ice showed that, whatever the site (Antarctica, Greenland, or the Alps), the $\mathrm{C}_{1}$ $\mathrm{C}_{3}$ monocarboxylic acids and $\mathrm{HCHO}$ represent the most important water-soluble atmospheric organic gases contributing to the $\mathrm{OC}$ content of ice, and that the remaining amount of DOC denoted WSOC* $\left(\left[\mathrm{WSOC}^{*}\right]=[\mathrm{DOC}]-[\right.$ Monoacid$\mathrm{C}]-[\mathrm{HCHO}-\mathrm{C}]$ ) would correspond to atmospheric WSOC aerosol. $\mathrm{C}_{2}-\mathrm{C}_{5}$ dicarboxylic acids, HULIS, and sometimes methanesulfonate were found to contribute to the $\mathrm{WSOC}^{*}$ quantity, but a large fraction remained chemically unidentified.

A preliminary discussion was done on the change from pre-industrial to present-day atmosphere that was detected in the Alps and Greenland. In a recent study, the case of the Alpine OC trend in summer ice was recently documented by $\mathrm{DO}^{14} \mathrm{C}$ measurements, suggesting that in spite of three times higher levels in the 1970s and 1980s compared to before World War II, a major fraction of WSOC is biogenic in origin. Many environmental parameters may have caused strengthened biogenic emissions of atmospheric WSOC including warmer temperatures, higher atmospheric $\mathrm{CO}_{2}$, and enhanced oxidative capacity of the atmosphere. For Greenland, it must be emphasized that the trend of OC increasing since the pre-industrial era is documented only by the level in pre-industrial ice level and in snow collected over the very recent years in snow pits. A complete study of the change between the pre-industrial times and the present day is limited by the fact that the cleaning of the firn material in view of DOC measurement remains difficult work. Finally, this paper reports for the first time a few data on the natural variability of the DOC content of ice in relation to sporadic arrival of forest fire plumes over Greenland or response to the last glacial-interglacial transition in Antarctica. Further Antarctic studies in coastal ice cores (and/or in the atmosphere at coastal sites) are strongly needed to better quantify the role of polar ocean emissions in Antarctica. 
Acknowledgements. We would like to thank D. Wagenbach and P. Stricker from the IUP Heidelberg for analytical efforts they have done over the last $10 \mathrm{yr}$ in contributing to making it possible to perform routine measurements of OC in low-level ice samples. This work was partly supported by European Commission through the project CARBOSOL (EVK2-2001-113) and by the CNRS-DFG French-German project "Secondary organic aerosol production in the lower free troposphere over western Europe". National financial support and field logistic supplies for the campaign at Concordia were provided by Institut Polaire Français-Paul Emile Victor (IPEV) within programme No. 414. These Antarctic activities took also advantage of the field campaign organized in 2011/2012 at Concordia within the framework of the OPALE project funded by the ANR (Agence National de Recherche) contract ANR-09BLAN-0226. The NEEM project is directed by the Centre for Ice and Climate at the Niels Bohr Institute, Copenhagen, and the US NSF OPP. It is supported by funding agencies and institutions in Belgium (FNRS-CFB and FWO), Canada (NRCan/GSC), China (CAS), Denmark (FIST), France (IPEV, CNRS/INSU, CEA, and ANR), Germany (AWI), Iceland (RannIs), Japan (NIPR), Korea (KOPRI), the Netherlands (NWO/ALW), Sweden (VR), Switzerland (SNF), the United Kingdom (NERC), and the United States (US NSF, OPP).

Edited by: E. Wolff

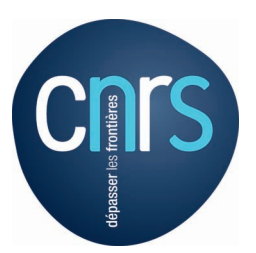

The publication of this article is financed by CNRS-INSU.

\section{References}

Anderson, C. H., Dibb, J. E., Griffin, R. J., Hagler, G. S. W., and Bergin, M. H.: Atmospheric water-soluble organic carbon measurements at Summit, Greenland, Atmos. Environ., 42, 56121621, 2008.

Antony, R., Mahalinganathan, K., Thamban, M., and Nair, S.: Organic carbon in Antarctic snow: Spatial trends and possible sources, Environ. Sci. Technol., 45, 9944-9950, 2011.

Booth, R., Furlong, J., and Wallace, B.: Selection of a TOC analyzer: Analytical considerations, Application note Fall 1999 (Tekmar, A Teledyne Technologie Company), Masen, OH, 1999.

Calace, N., Cantafora, E., Mirante, S., Petronio, B. M., and Pietroletti, M.: Transport and modification of humic substances present in Antarctic snow and ancient ice, J. Environ. Monit., 7, 13201325, 2005.

Ciais, P., Jouzel, J., Petit, J. R., and White, J. W. C.: Holocene temperature variations inferred from six Antarctic ice cores, Ann. Glaciol., 20, 427-436, 1994.

Clausen, H. B., Hammer, C. U., Hvidberg, C. D., Dahl-Jensen, D., Kipfstuhl, J., and Legrand M.: A comparison of the volcanic records over the past 4000 years from the Greenland Ice Core Project and Dye 3 Greenland ice cores, J. Geophys. Res., 102, 26707-26723, 1997.

De Angelis, M., Traversi, R., and Udisti, R.: Long-term trends of mono-carboxylic acids in Antarctica: comparison of changes in sources and transport processes at the two EPICA deep drilling sites, Tellus B, 64, 17331, doi:10.3402/tellusb.v64i0.17331, 2012.

Dibb, J. E. and Arsenault, M.: Shouldn't snowpacks be sources of monocarboxylic acids?, Atmos. Environ., 36, 2513-2522, 2002.

Eriksson, E.: The yearly circulation of chloride and sulfur in nature: meteorological, geochemical, and pedological implications, Part 1, Tellus, 11, 375-403, 1959.

Fagerli, H., Legrand, M., Preunkert, S., Vestreng, V., Simpson, D., and Cerqueira, M.: Modeling historical long-term trends of sulfate, ammonium, and elemental carbon over Europe: A comparison with ice core records in the Alps, J. Geophys. Res., 112, D23S13, doi:10.1029/2006JD008044, 2007.

Federer, U., Kaufmann, P. R., Hutterli, M., Schüpbach, S., and Stocker, T. F.: Continuous flow analysis of total organic carbon in polar ice cores, Environ. Sci. Technol., 42, 8039-8043, 2008.

Fischer, H., Wagenbach, D., and Kipfstuhl, J.: Sulfate and nitrate firn concentrations on the Greenland ice sheet, 1, Large-scale geographical deposition changes, J. Geophys. Res., 103, 2192721934, 1998.

Fried, A., Walega, J., Olson, J. R., Crawford, J. H., Chen, G., Weibring, P., Richter, D., Roller, C., Tittel, F. K., Heikes, B., Snow, J., Shen, H., O'Sullivan, D., Porter, M, Fuelberg, H., Halland, J., and Millet, D. B.: Formaldehyde over North America and the North Atlantic during the summer 2004 INTEX campaign: Methods, observed distributions, and measurement-model comparisons, J. Geophys. Res., 113, D10302, doi:10.1029/2007JD009185, 2008.

Gabrieli, J., Vallelonga, P., Cozzi, G., Gabrielli, P., Gambaro, A., Sigl, M., Decet, F., Schwikowski, M., Gäggeler, H., Boutron, C., Cescon, P., and Barbante, C.: Post 17th century changes of european PAH emissions recorded in high-altitude alpine snow and ice, Environ. Sci. Technol., 44, 3260-3266, 2010.

Gantt, B. and Meskhidze, N.: The physical and chemical characteristics of marine primary organic aerosol: a review, Atmos. Chem. Phys., 13, 3979-3996, doi:10.5194/acp-13-3979-2013, 2013.

Grannas, A., Shepson, P. B., and Filley, T. R.: Photochemistry and nature of organic matter in Arctic and Antarctic snow, Global Biogeochem. Cy., 18, GB1006, doi:10.1029/2003GB002133, 2004.

Guilhermet, J., Preunkert, S., Voisin, D., Baduel, C., and Legrand, M.: Major 20th century changes of water-soluble HUmic LIke Substances $\left(\right.$ HULIS $_{W S}$ ) aerosol over Europe inferred from Alpine ice cores, J. Geophys. Res. Atmos., 118, 3869-3878, doi:10.1002/jgrd.50201, 2013.

Hagler, G. S., Bergin, M. H., Smith, E. A., Dibb, J. E., Anderson, C., and Steig, E. J.: Particulate and water-soluble carbon measured in recent snow at Summit, Greenland, Geophys. Res. Lett., 34, L16505, doi:10.1029/2007GL030110, 2007a.

Hagler, G. S., Bergin, M. H., Smith, E. A., and Dibb, J. E.: A summer time series of particulate carbon in the air and snow at Summit, Greenland, J. Geophys. Res., 112, D21309, doi:10.1029/2007JD008993, 2007b.

Hodzic, A., Jimenez, J. L., Madronich, S., Canagaratna, M. R., DeCarlo, P. F., Kleinman, L., and Fast, J.: Modeling organic aerosols in a megacity: potential contribution of semi-volatile and intermediate volatility primary organic compounds to secondary organic aerosol formation, Atmos. Chem. Phys., 10, 5491-5514, doi:10.5194/acp-10-5491-2010, 2010. 
Houdier, S., Perrier, S., Defrancq, E., and Legrand, M.: A new fluorescent probe for sensitive detection of carbonyl compounds: Sensitivity improvement and application to environmental natural waters, Anal. Chem. Acta, 412, 221-233, 2000.

Hutterli, M. A., Rothlisberger, R., and Bales, R. C.: Atmosphereto-snow-to-firn transfer studies of HCHO at Summit, Greenland, Geophys. Res. Lett., 26, 1691-1694, 1999.

Hutterli, M., McConnell, J. R., Bales, R., and Steward, R.: Sensitivity of hydrogen peroxide $\left(\mathrm{H}_{2} \mathrm{O}_{2}\right)$ and formaldehyde ( $\left.\mathrm{HCHO}\right)$ preservation in snow to changing environmental conditions: Implications for ice core records, J. Geophys. Res., 108, 4023, doi:10.1029/2002JD002528, 2003.

Hutterli, M. A., McConnell, J. R., Chen, G., Bales, R. C., Davis, D. D., and Lenschow, D. H.: Formaldehyde and hydrogen peroxide in air, snow and interstitial air at South Pole, Atmos. Environ., 38, 5439-5450, 2004.

Jacobi, H. W., Frey, M., Hutterli, M. A., Bales, R. C., Schrems, O., Cullen, N. J., Steffen, K., and Koehler, C.: Measurements of hydrogen peroxide and formaldehyde exchange between the atmosphere and surface snow at Summit, Greenland, Atmos. Environ., 36, 2619-2628, 2002.

Jaffrezo, J.-L., Davidson, C. I., Legrand, M., and Dibb, J. E.: Sulfate and MSA in the air and snow on the Greenland ice sheet, J. Geophys. Res., 99, 1241-1253, 1994.

Jaffrezo, J.-L., Davidson, C. I., Kuhns, H. D., Bergin, M. H., Hillamo, R., Maenhaut, W., Kahl, J. W., and Harris, J. M.: Biomass burning signatures in the atmosphere of central Greenland, J. Geophys. Res., 103, 31067-31078, 1998.

Jimenez, J. L., Canagaratna, M. R., Donahue, N. M., Prevot, A. S. H., Zhang, Q., Kroll, J. H., DeCarlo, P. F., Allan, J. D., Coe, H., Ng, N. L., Aiken, A. C., Docherty, K. S., Ulbrich, I. M., Grieshop, A. P., Robinson, A. L., Duplissy, J., Smith, J. D., Wilson, K. R., Lanz, V. A., Hueglin, C., Sun, Y. L., Tian, J., Laaksonen, A., Raatikainen, T., Rautiainen, J., Vaattovaara, P., Ehn, M., Kulmala, M., Tomlinson, J. M., Collins, D. R., Cubison, M. J., Dunlea, E. J., Huffman, J. A., Onasch, T. B., Alfarra, M. R., Williams, P. I., Bower, K., Kondo, Y., Schneider, J., Drewnick, F., Borrmann, S., Weimer, S., Demerjian, K., Salcedo, D., Cottrell, L, Griffin, R., Takami, A., Miyoshi, T., Hatakeyama, S., Shimono, A., Sun, J. Y., Zhang, Y. M., Dzepina, K., Kimmel, J. R., Sueper, D., Jayne, J., Herndon, S. C., Trimborn, A. M., Williams, L. R., Wood, E. C., Middlebrook, A. M., Kolb, C. E., Baltensperger, U., and Worsnop, D. R.: Evolution of Organic Aerosols in the Atmosphere, Science, 326, 1525-1529, 2009.

Jourdain, B. and Legrand, M.: Seasonal variations of dimethyl sulfide, dimethyl sulfoxide, sulfur dioxyde, methanesulfonate, and non-sea-salt sulfate aerosols at Dumont d'Urville (December 1998-July 1999), J. Geophys. Res., 106, 14391-14408, 2001.

Jouzel, J., Raisbeck, G., Benoist, J. P., Yiou, F., Lorius, C., Raynaud, D., Petit, J. R., Barkov, N. I., Korotkevitch, Y. S., and Kotlyakov, V. M.: A comparison of deep Antarctic ice cores and their implications for climate between 65,000 and 15,000 years ago, Quat. Res., 31, 135-150, 1989.

Kawamura, K., Suzuki, I., Fujii, Y., and Watanabe, O.: Ice core record of fatty acids over the past 450 years in Greenland, Geophys. Res. Lett., 23, 2665-2668, doi:10.1029/96GL02428, 1996.

Kormann, R., Fischer, H., de Reus, M., Lawrence, M., Brühl, Ch., von Kuhlmann, R., Holzinger, R., Williams, J., Lelieveld, J., Warneke, C., de Gouw, J., Heland, J., Ziereis, H., and
Schlager, H.: Formaldehyde over the eastern Mediterranean during MINOS: Comparison of airborne in-situ measurements with 3D-model results, Atmos. Chem. Phys., 3, 851-861, doi:10.5194/acp-3-851-2003, 2003.

Legrand, M.: Ice-core records of atmospheric sulphur, Phil. Trans. R. Soc. Lond. B, 352, 241-250, 1997.

Legrand, M. and De Angelis, M.: Origins and variations of light carboxylic acids in polar precipitation, J. Geophys. Res., 100, 1445-1462, 1995

Legrand, M. and De Angelis, M.: Light carboxylic acids in Greenland ice: A record of past forest fires and vegetation emissions from the boreal zone, J. Geophys. Res., 101, 4129-4145, 1996.

Legrand, M. and Mayewski, P.: Glaciochemistry of polar ice cores: A review, Rev.Geophys., 35, 219-243, 1997.

Legrand, M. and Puxbaum, H.: Summary of the CARBOSOL project: Present and retrospective state of organic versus inorganic aerosol over Europe, J. Geophys. Res., 112, DS23S01, doi:10.1029/2006JD008271, 2007.

Legrand, M., De Angelis, M., Staffelbach, T., Neftel, A., and Stauffer, B.: Large perturbations of ammonium and organic acids content in the Summit Greenland ice core, fingerprint from forest fires?, Geophys. Res. Lett., 19, 473-475, 1992.

Legrand, M., Hammer, C., De Angelis, M., Savarino, J., Delmas, R., Clausen, H., and Johnson, S. J.: Sulphur containing species (MSA and $\mathrm{SO}_{4}$ ) over the last climatic cycle in the GRIP (central Greenland) ice core, J. Geophys. Res., 102, 26663-26679, 1997.

Legrand, M., Sciare, J., Jourdain, B., and Genthon, C.: Daily variations of dimethyl sulfide, dimethyl sulfoxide, methanesulfonate, and non-sea-salt sulfate aerosols at Dumont d'Urville (December 1998-March 1999), J. Geophys. Res., 106, 14409-14422, 2001.

Legrand, M., Preunkert, S., Wagenbach, D., Cachier, H., and Puxbaum, H.: A historical record of formate and acetate from a high elevation Alpine glacier: Implications for their natural versus anthropogenic budgets at the European scale, J. Geophys. Res., 108, 4788, doi:10.1029/2003JD003594, 2003.

Legrand, M., Preunkert, S., Schock, M., Cerqueira, M., KasperGiebl, A., Afonso, J., Pio, C., Gelencsér, A., and DombrowskiEtchevers, I.: Major 20th century changes of carbonaceous aerosol components (EC, WinOC, DOC, HULIS, carboxylic acids, and cellulose) derived from Alpine ice cores, J. Geophys. Res., 112, D23S11, doi:10.1029/2006JD008080, 2007a.

Legrand, M., Preunkert, S., Oliveira, T., Pio, C. A., Hammer, S., Gelencsér, A., Kasper-Giebl, A., and Laj, P.: Origin of $\mathrm{C}_{2}-\mathrm{C}_{5}$ dicarboxylic acids in the European atmosphere inferred from yearround aerosol study conducted at a west-east transect, J. Geophys. Res., 112, D23S07, doi:10.1029/2006JD008019, $2007 \mathrm{~b}$.

Legrand, M., Gros, V., Preunkert, S., Sarda-Estève, R., Thierry, A.-M., Pépy, G., and Jourdain, B.: A reassessment of the budget of formic and acetic acids in the boundary layer at Dumont d'Urville (coastal Antarctica): The role of penguin emissions on the budget of several oxygenated volatile organic compounds, J Geophys. Res., 117, D06308, doi:10.1029/2011JD017102, 2012.

Legrand, M., Preunkert, S., May, B., Guilhermet, J., Hoffmann, H., and Wagenbach, D.: Major 20th century changes of the content and chemical speciation of organic carbon archived in Alpine ice cores: implications for the long-term change of organic aerosol over Europe, J. Geophys. Res., Atmos., 118, 38793890, doi:10.1002/jgrd.50202, 2013. 
Lorius, C. and Merlivat, L: Distribution of mean surface stable isotope values in east Antarctica. Observed changes with depth in a coastal area, in: Isotopes and impurities in snow and ice, Proceedings of the Grenoble symposium Aug/Sep 1975, 118, IAHS Publication, IAHS, Vienna, 1977.

Lyons, W. B., Welch, K. A., and Doggett, J. K.: Organic carbon in Antarctic snow, Geophys. Res. Lett., 34, L02501, doi:10.1029/2006GL028150, 2007.

May, B., Wagenbach, D., Hoffmann, H., Legrand, M., Preunkert, S., and Steier, P.: Constraints on the major sources of dissolved organic carbon in Alpine ice cores from Radiocarbon analysis over the bomb peak period, J. Geophys. Res. Atmos., 118, 33193327, doi:10.1002/jgrd.50200, 2013.

Mayewski, P., Lyons, W. B., Spencer, M. J., Twickler, M., Dansgaard, C., Koci, B., Davidson, C. I., and Honrath, R. E.: Sulphate and nitrate concentrations from the south Greenland ice core, Science, 232, 957-977, 1986.

Mayol-Bracero, O. L., Guyon, P., Graham, B., Roberts, G., Andreae, M. O., Decesari, S., Facchini, M. C., Fuzzi, S., and Artaxo, P.: Water-soluble organic compounds in biomass burning aerosols over Amazonia 2, Apportionment of the chemical composition and importance of the polyacidic fraction, J. Geophys. Res., 107, 8091, doi:10.1029/2001JD000522, 2002.

Parrenin, F., Remy, F., Ritz, C., Siegert, M., and Jouzel, J.: New modelling of the Vostok ice flow line and implication for the glaciological chronology of the Vostok ice core, J. Geophys. Res., 109, D20102, doi:10.1029/2004JD004561, 2004.

Paulot, F., Wunch, D., Crounse, J. D., Toon, G. C., Millet, D. B., DeCarlo, P. F., Vigouroux, C., Deutscher, N. M., González Abad, G., Notholt, J., Warneke, T., Hannigan, J. W., Warneke, C., de Gouw, J. A., Dunlea, E. J., De Maziére, M., Griffith, D. W. T., Bernath, P., Jimenez, J. L., and Wennberg, P. O.: Importance of secondary sources in the atmospheric budgets of formic and acetic acids, Atmos. Chem. Phys., 11, 1989-2013, doi:10.5194/acp-11-1989-2011, 2011.

Pio, C. A., Legrand, M., Oliveira, T., Afonso, J., Santos, C., Caseiro, A., Fialho, P., Barata, F., Puxbaum, H., Sanchez-Ochao, A., Kasper-Giebl, A., Gelencsér, A., Preunkert, S., and Schock, M.: Climatology of aerosol composition (organic versus inorganic) at non-urban sites on a west-east transect across Europe, J. Geophys. Res., 112, D23S02, doi:10.1029/2006JD008038, 2007.

Preunkert, S. and Legrand, M.: Towards a quasi-complete reconstruction of past atmospheric aerosol load and composition (organic and inorganic) over Europe since 1920 inferred from Alpine ice cores, Clim. Past, 9, 1403-1416, doi:10.5194/cp-91403-2013, 2013.

Preunkert, S., Legrand, M., and Wagenbach, D.: Sulfate trends in a Col du Dôme (French Alps) ice core: A record of anthropogenic sulfate levels in the European mid-troposphere over the 20th century, J. Geophys. Res., 106, 31991-32004, 2001.

Preunkert, S., Legrand, M., Jourdain, B., and DombrowskiEtchevers, I.: Acidic gases $\left(\mathrm{HCOOH}, \mathrm{CH}_{3} \mathrm{COOH}, \mathrm{HNO}_{3}, \mathrm{HCl}\right.$, and $\mathrm{SO}_{2}$ ) and related aerosol species at a high mountain Alpine site (4360 m elevation) in Europe, J. Geophys. Res., 112, D23S12, doi:10.1029/2006JD008225, 2007.

Preunkert, S., Jourdain, B., Legrand, M., Udisti, R., Becagli, S., and Cerri, O.: Seasonality of sulfur species (sulfate, methanesulfonate and dimethyl sulfur) in Antarctica: inland versus coastal regions, J. Geophys. Res., 113, D15302,
doi:10.1029/2008JD009937, 2008.

Preunkert, S., Legrand, M., Stricker, P., Bulat, S., Alekhina, I., Petit, J. R., Hoffmann, H., May, B., and Jourdain B.: Quantification of Dissolved Organic Carbon at very low levels in natural ice samples by a UV induced oxidation method, Environ. Sci. Technol., 45, 673-678, 2011.

Putaud, J.-P., Raes, F., Van Dingenen, R., Brüggemann, E., Facchini, M.-C., Decesari, S., Fuzzi, S., Gehrig, R., Hüglin, C., Laj, P., Lorbeer, G., Maenhaut, W., Mihalopoulos, N., Müller, K., Querol, X., Rodriguez, S., Schneider, J., Spindler, G., ten Brink, H., Tørseth, K., and Wiedensohler, A.: A European aerosol phenomenology 2: Chemical characteristics of particulate matter at kerbside, urban, rural and background sites in Europe, Atmos. Environ., 38, 2579-2595, 2004.

Rasmussen, S. O., Abbott, P., Blunier, T., Bourne, A., Brook, E., Buchardt, S. L., Buizert, C., Chappellaz, J., Clausen, H. B., Cook, E., Dahl-Jensen, D., Davies, S., Guillevic, M., Kipfstuhl, S., Laepple, T., Seierstad, I. K., Severinghaus, J. P., Steffensen, J. P., Stowasser, C., Svensson, A., Vallelonga, P., Vinther, B. M., Wilhelms, F., and Winstrup, M.: A first chronology for the NEEM ice core, Clim. Past Discuss., 9, 2967-3013, doi:10.5194/cpd-92967-2013, 2013.

Ruth, U., Barbante, C., Bigler, M., Delmonte, B., Fischer, H., Gabrielli, P., Gaspari, V., Kaufmann, P., Lambert, F., Maggi, V., Marino, F., Petit, J. R., Udisti, R., Wagenbach, D., Wegner, A., and Wolff, E.: Proxies and measurement techniques for mineral dust in Antarctic ice cores, Environ. Sci. Technol., 42, 56755681, 2008.

Saltzman, E. S., Whung, P.-Y., and Mayewski, P.: Methanesulfonate in the Greenland ice sheet project 2 ice core, J. Geophys. Res., 102, 26649-26657, 1997.

Savarino, J. and Legrand, M.: High northern latitude forest fires and vegetation emissions over the last millenium inferred from the chemistry of a central Greenland ice core, J. Geophys. Res., 103, 8267-8279, 1998.

Schwikowski, M., Döschler, A., Gäggeler, H. W., and Schotterer, U.: Anthropogenic versus natural sources of atmospheric sulphate from an Alpine ice core, Tellus, Ser. B, 51, 938-951, 1999.

Silvente, E. and Legrand, M.: Ammonium to sulphate ratio in aerosol and snow from Greenland and Antarctic regions, Geophys. Res. Lett., 20, 687-690, 1993.

Simpson, D., Yttri, K. E., Klimont, Z., Kupiainen, K., Caseiro, A., Gelencser, A., Pio, C., Puxbaum, H., and Legrand, M.: Modeling carbonaceous aerosol over Europe: Analysis of the CARBOSOL and EMEP EC/OC campaigns, J. Geophys. Res., 112, D23S14, doi:10.1029/2006JD008158, 2007.

Staffelbach, T., Neftel, A., Stauffer, B., and Jacob, D.: A record of the atmospheric methane sink from formaldehyde in polar ice cores, Nature, 349, 603-605, 1991.

Turpin, B., Saxena, P., and Andrews, E.: Measuring and simulating particulate organics in the atmosphere: Problems and prospects, Atmos. Environ., 34, 2983-3013, 2000.

Twickler, M. S., Spencer, M. J., Lyons, W. B., and Mayewski, P. A.: Measurement of organic carbon in polar snow samples, Nature, 320, 156-158, 1986.

Wagenbach, D.: Coastal Antarctica: Atmospheric chemical composition and atmospheric transport, in Chemical Exchange Between the Atmosphere and Polar Snow, NATO ASI. Ser. I, vol. 43, edited by: Wolff, E. W. and Bales, R. C., 173-199, Springer- 
Verlag, New York, 1996.

Wolff, E. W., Fischer, H., Fundel, F., Ruth, U., Twarloh, B., Littot, G. C., Mulvaney, R., Rothlisberger, R., De Angelis, M., Boutron, C. F., Hansson, M., Jonsell, U., Hutterli, M. A., Lambert, F., Kaufmann, P., Stauffer, B., Stocker, T. F., Steffensen, J. P., Bigler, M., Siggaard-Andersen, M. L., Udisti, R., Becagli, S., Castellano, E., Severi, M., Wagenbach, D., Barbante, C., Gabrielli, P., and Gaspari, V.: Southern Ocean sea-ice extent, productivity and iron flux over the past eight glacial cycles, Nature, 440, 491-496, doi:10.1038/nature04614, 2006.
Yao, T. D., Petit J.-R., Jouzel, J., Lorius, C., and Duval, P.: Climatic record from an ice margin area in East Antarctica, Ann. Glaciol., 14, 323-327, 1990.

Zorn, S. R., Drewnick, F., Schott, M., Hoffmann, T., and Borrmann, S.: Characterization of the South Atlantic marine boundary layer aerosol using an aerodyne aerosol mass spectrometer, Atmos. Chem. Phys., 8, 4711-4728, doi:10.5194/acp-8-47112008, 2008. 